\title{
Colorblind Segregation: Equal Protection as a Bar to Neighborhood Integration
}

\author{
Michelle Wilde Anderson $\dagger$
}

\section{TABLe of Contents}

Introduction

I. Dallas: A Case Study in Systemic Spatial Exclusion .................... 848

A. The Story of the Walker Litigation ....................................... 848

B. Enforcing Segregation: Municipal Actors Divide the City....... 850

C. The Fifth Circuit Decision ................................................. 853

II. The Colorblindness Frontier: Curtailing Desegregation ................ 858

A. Restraining Courts' Remedial Authority Under the Fourteenth Amendment.

B. The Lost Parties: A Collision of Equal Protection Rights ........ 865

C. Narrow Tailoring Becomes Fatal in Fact................................. 866

D. A Turn Towards Non-State Actors .......................................... 868

III. What Remedy? Assessing the Integration Mandate........................ 869

A. Foreclosing Effective Remedies Under the FHA .................... 871

B. Reconcentrating the Ghetto: Forcing Vouchers as a Catch-All Solution

IV. The Result: Zones of Exclusion ........................................... 879

A. Perpetuating Inequality Through Rational Exclusion............... 879

B. Serious Remedies to Segregation: The Integration Imperative . 882

Copyright 12004 California Law Review, Inc. California Law Review, Inc. (CLR) is a California nonprofit corporation. CLR and the authors are solely responsible for the content of their publications.

$\dagger \quad$ J.D. Candidate, School of Law, University of California, Berkeley (Boalt Hall), May 2004; MSc. Urban and Regional Planning, London School of Economics \& Political Science, 2000; B.A., Yale University, 1997. I am deeply indebted to my mentors in urban racial history, Henry Femandez and Mercedes Soto. They taught me more than 1 could hope to capture using the language of law. This Comment would not have been possible without the intellectual and personal contributions of lan Haney López, Rachel Moran, Karen Tumlin, and Sade Borghei. My thanks also to Angela Harris, Margalynne Armstrong, Kevin Bundy, Jane Larson, and other participants at the 2003 Law \& Society Conference, where I first presented this paper, as well as the talented editorial staff of the California Law Review. 


\title{
Colorblind Segregation: Equal Protection as a Bar to Neighborhood Integration
}

\author{
Michelle Wilde Anderson
}

\section{INTRODUCTION}

On the outskirts of the city of Dallas are the vestiges of a sprawling public housing project of 3,500 units known simply as West Dallas. ${ }^{1}$ The city built the project in 1955 as a solution to the "Negro Housing Problem": the fear that the strong private market demand for rental housing among African Americans would lead to black encroachment into white neighborhoods, and that such integration pressure might meet violent white resistance. ${ }^{2}$ Not one dollar was spent on maintenance or modernization for ten years during the late I960s and 1970s, because the Dallas Housing Authority (DHA) lost all federal revenue for refusing to comply with federal fair housing laws. ${ }^{3}$ Throughout the life of the project, West Dallas residents have been alienated from employment opportunities, city services, and amenities. ${ }^{4}$ Many of them suffered severe health effects caused by an adjacent lead smelter. ${ }^{5}$ In I975, rapes in the area were over six times more frequent than elsewhere in the city and West Dallas residents were five times more likely to be murdered. ${ }^{6}$ In the 1980 s, as with other large-scale public housing projects across the country, residents and housing advocates clamored for West Dallas's demolition. ${ }^{7}$ Yet some political groups in the city objected because, in the words of a Dallas federal court, "they suddenly discovered how important it was to keep 3500 units of low-income housing for blacks in West Dallas."

Intervening in this human tragedy and political controversy in 1989, a federal district judge ordered the DHA and city council to take affirmative

1. Walker v. United States Dep't of Hous. \& Urban Dev., 734 F. Supp. 1289, 1295-96 (N.D. Tex. 1989) ("Walker III").

2. Id. at 1295 (discussing the resistance to integration documented in the Dallas city council records).

3. Id. at $\mathbf{1 2 9 7 - 9 8 .}$

4. Id. at 1296 .

5. Id. at $\mathrm{I} 307$.

6. Id.

7. Id. at 1308 .

8. Id. at $1310 \mathrm{nn} .66-67$. 
steps to remedy their egregious patterns of housing segregation. ${ }^{9}$ The court ordered the selective demolition of West Dallas and other isolated ghettoes, the opening of the city's private housing markets to subsidized housing vouchers, and the construction of ncw, small-scale housing in white, lowpoverty neighborhoods. ${ }^{10}$ The court noted that previously,

[a]ny and every attempt to select public housing in white areas, whether under a court order or a color-blind selection process, has met with strenuous and effective neighborhood and political opposition. Absent a court order requiring the construction of public housing in white areas, the housing is either developed in minority areas or it is not developed at all. ${ }^{11}$

In 1999, in Walker v. City of Mesquite, Texas ("Walker V') the Fifth Circuit rejected the lower court's finding that exclusively colorblind remedies could not overcome the DHA's explicit practice of segregation and racial discrimination. ${ }^{12}$ In a case challenging the constitutionality of the district court's race-conscious remedial order, the court upheld the Fourteenth Amendment equal protection claim of white homeowners near a Dallas site proposed for a forty-unit public housing development. ${ }^{13}$ The homeowners claimed that due to the remedial provision mandating new construction of public housing in white neighborhoods, they were "purposefully discriminated against because of their race."14 The court recognized the homeowners' injury and ordered a stay of construction on the building. ${ }^{15}$ No public housing has since been built on the site. ${ }^{16}$

Walker $V$ is not alone in bringing reverse discrimination claims into the realm of residential desegregation. A challenge to race-conscious court orders also arose in the Second Circuit, where the City of Yonkers appealed the constitutionality of a district court's remedial desegregation order. ${ }^{17}$ In contrast to the Fifth Circuit, the Second Circuit upheld the

9. Id. at 1290 . The full procedural history of the Walker litigation is diseussed infra Part Il.A and note 38 .

10. Walker v. United States Dep't of Hous. \& Urban Dev., No. 3:85-CV-1210-R, 1997 WL 33177466 (N.D. Tex. Oct. 6, 1997) ("Walker 10/6/97 Written Opinion") (memorandum opinion), rev'd in part, vacated in part, 169 F.3d 973 (5th Cir. 1999).

11. Id. at 10 (emphasis added).

12. Walker v. City of Mesquite, 169 F.3d 973 (5th Cir. 1999) ("Walker V"), cert. denied, 528 U.S. 1131 (2000).

13. Id. at $987-88$.

14. Id. at 979 .

15. Id. at $985-88$.

16. Due to the homeowners' opposition and their legal victory in 1999 , development has been on hold since 1996, when the DHA purchased the land. In December 2003, the DHA requested the district eourt's permission to carry out its plans for the site, arguing that the property satisfied criteria approved by the Fifth Circuit. The homeowners argued that Walker $V$ forbids such construction. See Kim Horner, Agency Asks Judge to OK Housing Project; Far N. Dallas Residents Have Opposed Federally Subsidized Complex, Dallas Morning News, Dec. 19, 2003, at 3B.

17. United States v. Sec'y of Hous. \& Urban Dev., 239 F.3d 211 (2d Cir. 2001) (considering the constitutionality of remedial orders issued in the famously contentious school and housing 
race-conscious remedy and its explicit integration objectives in United States v. Secretary of Housing and Urban Development ("Yonkers"), finding that those measures served as a necessary step towards overcoming past and present discrimination. ${ }^{18}$ The Supreme Court denied certiorari on both cases, ${ }^{19}$ and the question of race consciousness in residential desegregation remedies has been widely overlooked in the years following. ${ }^{20}$

Notwithstanding the fact that a majority of the Supreme Court refused to follow the Fifth Circuit's equal protection jurisprudence in a recent decision, Grutter v. Bollinger, ${ }^{21}$ Walker $V$ casts a long shadow in equal protection jurisprudence. The decision suggests a new direction in colorblindness doctrine: restraint of courts' remedial power to redress constitutional violations involving race. ${ }^{22}$ In holding that courts may not use race-conscious provisions to enforce equitable relief, Walker $V$ extended a line of Supreme Court precedent in the reverse discrimination context further than the Court itself had gone, ${ }^{23}$ and, in so doing, functionally bypassed a Supreme Court decision allowing race-consciousness in a factually identical context. ${ }^{24}$

desegregation litigation beginning with United States v. Yonkers Board of Education, 635 F. Supp. 1577 (S.D.N.Y. 1986)). For a general history of the complex social, political, and legal history of the Yonkers desegregation litigation, see LiSa Belkin, Show ME a Hero: A TALE of Murder, Suicide, RACE, AND REDEMPTION (1999), and Jonathan L. Entin, Learning From Yonkers: On Race, Class, Housing, and Courts, 44 How. L.J. 375 (2001).

18. 239 F.3d at 219.

19. City of Yonkers v. United States, 534 U.S. 1054 (2001), denying cert. to Sec'y of Hous. \& Urban Dev., 239 F.3d 211 ; Walker v. City of Mesquite, 528 U.S. 1131 (2000), denying cert. to Walker V, 169 F.3d 973.

20. There are a few notable explorations of Walker $V$ in the commentary. See Michelle Adams, Intergroup Rivalry, Anti-Competitive Conduct and Affirmative Action, 82 B.U. L. REv. 1089 (2002) (exploring how Walker $V$ protected the racial distribution of neighborhood advantages by locking in the effects of segregation); Martha R. Mahoney, Whiteness and Remedy: Under-Ruling Civil Rights in Walker v. City of Mesquite, 85 CoRnell L. Rev. 1309 (2000) (exploring the decision through the lens of Critical Race Theory); Thomas Peter Abt, Comment, Another Dream Deferred? Walker v. City of Mesquite and the Threat to Meaningful Desegregation Remedies, 7 GEO. J. ON POVERTY L. \& POL'Y 123 (2000) (arguing that $W$ alker $V$ failed to distinguish race consciousness from racial preferences).

21. $123 \mathrm{~S}$. Ct. 2325 (2003). Outside the context of higher education, the applicability of Grutter's equal protection holding remains uncertain, but at the very least the decision reaffirmed that diversity can be a compelling state interest in the education context. See discussion infra note 24.

22. For a description of colorblindness theory and doctrine generally, see Alan D. Freeman, Legitimizing Racial Discrimination Through Antidiscrimination Law: A Critical Review of Supreme Court Doctrine, 62 MinN. L. REv. 1049 (1978).

23. In United States v. Paradise, 480 U.S. 149 (1987), a decision squarely addressing this point, the Court upheld a race-conscious, court-ordered remedial program to integrate a state employer. See infra Part Il.A for a discussion of the interaction of Paradise with the colorblindness doctrine of Adarand Constructors, Inc. v. Pena, 515 U.S. 200 (1995).

24. See Hills v. Gautreaux, 425 U.S. 284 (1976), discussed infra Part ll.A. In Hopwood v. Texas, the Fifth Circuit similarly pushed the margins of existing colorblindness doctrine by minimizing the relevance of Supreme Court precedent. Compare Hopwood v. Texas, 78 F.3d 932, 944-45 (5th Cir. 1996) (suggesting that the Court decision in Bakke was no longer good law), with Regents of the Univ. of Cal. v. Bakke, 438 U.S. 265, 267 (1978) (upholding some forms of affirmative action). While the circuit's decision in Hopwood was partially curtailed in the recent affirmative action decision, Grutter v. Bollinger, the Fifth Circuit's reasoning surfaced in the companion opinion Gratz v. Bollinger, 
Beyond its doctrinal implications, the Fifth Circuit's restriction on remedial desegregation interacts with current housing policies to prevent meaningful ways for public housing authorities to use race-neutral means to overcome their past role in maintaining and enforcing racial segregation. Together, this confluence of doctrine and policy might be called colorblind segregation jurisprudence: a framework in which court-ordered remedies for unconstitutional segregation and housing discrimination must be raceneutral, thereby preserving existing patterns of neighborhood advantage polarized by race.

This Comment uses Walker $V$ as a case study to explore the meaning and potential consequences of a colorblind segregation regime. Part I describes the Walker litigation and the role of public housing as an organizing force for segregation in Dallas. Part II explores colorblind segregation jurisprudence, defining the shape of the equal protection doctrine that structures Walker $V$ and its consequences for judicial discretion to remedy segregation organized by public housing. Applying these consequences in the context of current desegregation litigation and housing policy, Part III evaluates available remedies for constitutional and statutory violations by public housing authorities and investigates the effects of race neutrality in a public housing system that is increasingly privatized. Finally, Part IV explores the results of this intersection of colorblindness doctrine and privatization: the ostensibly race-neutral perpetuation of current patterns of urban inequality along the lines of both race and class.

Underlying this inquiry into colorblind segregation jurisprudence lurks a question at the heart of the Second Reconstruction: when a state actor is found liable for implementing an explicit program of unconstitutional racial segregation, how far must a court go towards dismantling the entrenched edifice of urban scale racial divisions? The cease-and-desist, nondiscrimination principle of the fair housing movement provided an important starting point. ${ }^{25}$ Yet alone, elimination of entry barriers may be unable to provide meaningful redress for the thousands of families whose precious access to affordable housing lies trapped in neighborhoods scarred by racial exclusion and poverty. ${ }^{26}$ The solutions at issue in Walker $V$ go

demonstrating the significance of the Fifth Circuit colorblindness jurisprudence for equal protection doctrine nationally. See Grutter v. Bollinger, $123 \mathrm{~S}$. Ct. 2325 (2003); Gratz v. Bollinger, $123 \mathrm{~S}$. Ct. 2411 (2003).

25. For a history of the fair housing movement, see Wendell E. Pritchett, Where Shall We Live? Class and the Limitations of Fair Housing Law, 35 URB. LAw. 399 (2003).

26. For documentation of the conditions and challenges facing residents concentrated in lowincome urban neighborhoods, including public housing developments, see generally SUDHIR ALLADI Venkatesh, American Project: The Rise and Fall of a Modern Ghetto (2000); William Julius Wilson, When Work Disappears: The World of the New URban Poor (1996) [hereinafter Wilson, WhEN WORK Disappears]; William Julius WILSON, ThE TRULY Disadvantaged: The Inner City, The Underclass, and Public Policy (1987) [hereinafter Wilson, The Truly Disadvantaged. 
further, reaching beyond nondiscrimination into proactive measures to achieve class diversity and racial integration. In exploring this spectrum of remedial approaches, this Comment takes as its premise that segregation itself generates tragic conditions of social isolation, economic abandonment, and neighborhood stigmatization. ${ }^{27}$ While such conditions implicate challenging issues of economic polarization, socioeconomics alone cannot explain the persistence of segregation and inequality in public housing. ${ }^{28}$ Race remains deeply imbedded in the historical and present-day distribution of public housing. ${ }^{29}$ The majority of non-elderly public housing remains racially identifiable, and developments occupied by white residents are disproportionately located in more affluent areas. ${ }^{30}$ The ongoing racial ordering of public housing is thus a critical factor in evaluating meaningful remedies for segregation.

If the severely depressed conditions of inner-city public housing are a product of racial segregation, as the histories of Dallas and other cities convey, then rational fear of the social effect of such conditions cannot be used as an argument to resist integration. On the contrary, the harms wrought by segregation obligate courts to remedy the state role in administering segregation by unraveling its lasting effects. ${ }^{31}$ Without such a

27. Extensive sociological research supports this premise. See, e.g., Douglas S. Massey \& Nancy A. Denton, American Apartheid: Segregation and the Making of the Underclass (1993) (documenting the dramatic social consequences of residential segregation).

28. The conflict over the siting of public housing has long been a battleground over the racial and economic integration of urban America. It has been both praised and vilified by all points on the political spectrum. It has been blamed for organizing and entrenching racial segregation, praised as a last great hope in achieving racial and class integration, and criticized for interfering with market forces and self-sufficicncy. Compare ARnold R. Hirsch, Making the Ghetto: Race and Housing in Chicago, 1940-1960 (1983), and Cara Hendrickson, Racial Desegregation and Income Deconcentration in Public Housing, 9 Geo. J. ON Poverty L. \& Pol'y 35 (2002), with Peter H. Schuck, Judging Remedies: Judicial Approaches to Housing Segregation, 37 HARv. C.R.-C.L. L. REv. 289 (2002). Even public housing's strongest advocates admit strong ambivalence about its past, while nevertheless believing in its reform potential. See, e.g., Michael H. Schill, Distressed Public Housing: Where Do We Go From Here?, 60 U. CHI. L. REv. 497 (1993) (discussing historic discrimination in the site selection of public housing).

29. See Michelle Adams, Separate and [Un]Equal: Housing Choice, Mobility, and Equalization in the Federally-Subsidized Housing Program, 7 I TuL. L. Rev. 413 (1996).

30. A HUD study documents that despite small declines in public housing segregation, the majority of African-American residents continue to live in neighborhoods that are disproportionately nonwhite and high poverty. By contrast, the majority of white public housing residents live in "more affluent" white neighborhoods. U.S. Dep't of Hous. and Urban Dev., Abstract, The Location and Racial Composition of Public Housing in the United States (1994), http://www.huduscr.org/ publications/pubasst/location.html. In addition, though low-income whites consume the majority of total housing subsidics, people of color disproportionately occupy project-based public housing, the most contentious form of housing support. Adams, supra note 29, at 441-42. The landscape of housing subsidies includes: mortgage interest and real estate tax deductions, federally insured mortgages, loan guarantees for veterans, and others. $I d$. at 416 n.2.

31. The premise is unaffectcd by the fact that uncritical adherence to a goal of racial integration, as opposed to equalization of neighborhood advantage, has become the source of extensive academic debate. By emphasizing community empowermont and neighborhood choice, however, such scholars 
remedial commitment, the overlay of equal protection law and housing policy within a colorblind segregation regime threatens to thwart progress towards the economic and social diversity that is widely seen as essential to the health of American cities and the achievement of equal opportunity. ${ }^{32}$

\section{I}

\section{Dallas: A Case Study in Systemic Spatial Exclusion}

May a court order racial integration as a remedy for systemic, explicit racial discrimination and segregation in housing perpetuated by state actors? In 1976, the Supreme Court answered yes as a matter of "well-established federal housing policy." "I3 1999 , the Fifth Circuit answered no, relegating the prior Supreme Court decision to a footnote and dismissing it as out of touch with current urban policy and race law. ${ }^{34}$ In the years in between, desegregation cases developed in public housing authorities across the country, ${ }^{35}$ including the Walker litigation in Dallas. In that case, a group of plaintiffs brought suit under the Equal Protection Clause of the Fourteenth Amendment for pattern discrimination and segregation perpetuated by the DHA and other state actors. Over the course of a complex litigation sequence, findings of "blatant," "deliberate" segregation and discrimination against African-American households ${ }^{36}$ were superceded by claims of inherent stigma in the racial classification of white homeowners. This Part provides a descriptive account of the Walker litigation, including its procedural trajectory, underlying urban history, and ultimate transformation into a reverse discrimination case.

\section{A. The Story of the Walker Litigation}

The Walker litigation sequence spanned sixteen years and two plaintiff classes. The first class included 7,200 black households ${ }^{37}$ living in

nevertheless embrace the underlying goal of dismantling racialized economic stratification, and they recognize the role of segregation in building such inequality. See, e.g., John O. Calmore, Spatial Equality and the Kerner Commission Report: A Back-to-the-Future Essay, 71 N.C. L. REv. 1487 (1993); Michael R. Tein, Comment, The Devaluation of Nonwhite Community in Remedies for Subsidized Housing Discrimination, 140 U. PA. L. REv. 1463 (1992); Adams, supra note 29.

32. Sheryll D. Cashin has argued the importance of economic diversity for alleviating social stratification along lines of race. See Sheryll D. Cashin, Drifting Apart: How Wealth and Race Segregation are Reshaping the American Dream, 47 VILL. L. REv. 595, 596 (2002).

33. Hills v. Gautreaux, 425 U.S. 284, 301 (1976).

34. Walker V, 169 F.3d 973, 832 n.20 (5th Cir. 1999), cert. denied, 528 U.S. 1131 (2000).

35. For a history of desegregation lawsuits filed against HUD following the passage of fair housing laws in the 1960s, see Florence Wagman Roisman, Long Overdue: Desegregation Litigation and Next Steps to End Discrimination and Segregation in the Public Housing and Section 8 Existing Housing Programs, 4 CitYSCAPE 171, 173 (1999).

36. Walker III, 734 F. Supp. 1289, 1293 (N.D. Tex. 1989).

37. Walker v. United States Dep't of Hous. \& Urban Dev., 734 F. Supp. 1231 app. B at 1263 (N.D. Tex. 1989) ("Walker l") (reprinting the January 20, 1987 consent decree and appending Class Action Findings of Fact and Conclusions of Law Approving the Proposed Consent Decree). 
DHA projects or participating in the DHA's housing voucher program. Their equal protection claim launched a series of legal events: a consent decree with the DHA and the United States Department of Housing and Urban Development (HUD), intervening legislation, joinder of a new defendant (the City of Dallas), court findings of repeated violations of the consent decree, and a remedial order instructing the DHA to redress its past practices of systemic discrimination and segregation. ${ }^{38}$ The remedial order, in turn, spawned the second class of plaintiffs, two white homeowners and their homeowners' associations who sued under the Equal Protection Clause for the injury of racial classification. ${ }^{39}$ This section describes the Walker litigation trajectory.

In 1987, Debra Walker and a class of black families brought suit under the FHA and the Equal Protection Clause for an "unbroken pattern of purposeful racial segregation and discrimination by DHA dating from the inception of DHA's program to the present day." ${ }^{40}$ The plaintiffs reached a consent decree with the agency requiring it to end discriminatory provision of services, improve city-wide housing choice for participants, and develop a demolition and revitalization program for West Dallas, arguably the city's most distressed and segregated public housing neighborhood. ${ }^{41}$ In 1989 , the district court held that the DHA had committed "repeated and pervasive" violations of several of the consent decree's antidiscrimination,

38. The litigation sequence is as follows: Walker l, $734 \mathrm{~F}$. Supp. 1231 (holding that the DHA had violated the parties' 1987 consent decree by failing to meet deadlines for changes to the tenant mobility program and the building of new units of housing); Walker v. United States Dep't of Hous. \& Urban Dev., 734 F. Supp. 1272 (N.D. Tex. 1989) ("Walker ll") (holding that (1) an intervening federal law prohibiting the use of funds for the demolition of housing in West Dallas was unconstitutional, (2) a separate federal statute prohibiting public housing demolition in certain circumstances was not unconstitutional, and (3) the latter statute did not apply to the case at bar); Walker III, 734 F. Supp. 1289 (joining the City of Dallas as a defendant subject to the consent decree because the city was a substantial cause of the deliberate racial segregation); Walker v. United States Dep't of Hous. \& Urban Dev., 912 F.2d 819 (5th Cir. 1990) ("Walker IV") (reversing the lower court judgment in Walker $I I$ to uphold a federal statute interfering with funding necessary to implement aspects of the consent decree); Walker 10/6/97 Written Opinion, No. 3:85-CV-1210-R, 1997 WL 33177466 (N.D. Tex. Oct. 6, 1997) (memorandum opinion) (rejecting the claim of white homeowners that the court's remedial order violated the Fourteenth Amendment); Walker V, 169 F.3d 973 (5th Cir. 1999) (upholding the equal protection challenge of white homeowners to the race-conscious aspects of the lower court's remedial order), cert. denied, 528 U.S. 1131 (2000); Walker v. United States Dep't of Hous. \& Urban Dev., No. 3:85 CV-1210-R, 2001 WL 1148109 (N.D. Tex. Sept. 18, 2001) (rejecting the homeowners' claim for attorney fees); Walker v. City of Mesquite, 313 F.3d 246 (5th Cir. 2002), cert. denied, 123 S. Ct. 1763 (2003) (reversing the lower court on the issue of the homeowners' entitlement to attorney fees).

39. In fact, an additional set of homeowners, residing in a different area of Dallas, had sued a few years earlier to block the citing of public housing in their neighborhood. Their suit, alleging a violation of housing authority site selection criteria, was dismissed in 1998 and sanctioned as frivolous. See Walker v. United States Dep't of Hous. \& Urban Dev., No. 3:85-CV-1210-R, 1998 WL 320295 (N.D. Tex. June 11, 1998).

40. Walker I, 734 F. Supp. app. A at 1247.

41. See id. app. A at 1248-51. 
voucher expansion, and code enforcement provisions. ${ }^{42}$ In a subsequent decision, it joined the City of Dallas as a defendant, holding it liable for promoting segregation and discrimination within Dallas public housing. ${ }^{43}$

Finding that the defendants had systematically defied and obstructed implementation of the consent decree, the court ordered progress towards integrated housing through the distribution of mobile housing vouchers, replacement housing for the residents of West Dallas, and the construction of new units of site-based public housing in low-poverty, predominantly white neighborhoods. ${ }^{44}$ Under the court's supervision, the DHA and HUD became "cooperating" defendants and commenced their remedial obligations by selecting two sites for construction in "predominantly white neighborhoods." 45 In response, white homeowners living near two sites selected for forty-unit developments filed suit. ${ }^{46}$ The same district court judge who had ordered the remedy rejected the homeowners' Fourteenth Amendment claim, holding that race-conscious site selection was a necessary last resort due to the defendants' obstruction of his earlier, race-neutral orders. ${ }^{47}$ The Fifth Circuit reversed this finding and vacated the raceconscious aspects of the order in Walker $V^{48}$

\section{B. Enforcing Segregation: Municipal Actors Divide the City}

The factual foundation of the Walker litigation is a story of four decades of legal obstructionism, intentional racial exclusion, and racial ghettoization perpetuated by the DHA and city council. ${ }^{49}$ The chain of policies and events in the case, which were before the lower court for more than ten years, led the district court judge to conclude that a race-conscious remedy mandating limited, conditional public housing construction in white neighborhoods provided the only means to overcome the entrenched patterns of segregated public housing development that had continuously disadvantaged the black residents of Dallas. ${ }^{50}$ In order to contextualize the

42. Id. at $1232-33$.

43. Walker III, 734 F. Supp. at 1290.

44. See Walker $V, 169 \mathrm{~F} .3 \mathrm{~d}$ at $977-78$ (outlining the provisions of the district court's unpublished 1995 remedial order affecting the DHA).

45. Walker 10/6/97 Written Opinion, No. 3:85-CV-1210-R, 1997 WL 33177466, at *1 (N.D. Tex. Oct. 6, 1997).

46. Walker $V, 169$ F.3d at 978.

47. See Walker 10/6/97 Written Opinion, 1997 WL 33177466, at*8-17 (cataloguing the DHA's failures to implement the court's consent decree and the failure of colorblind remedies).

48. The detailed holdings and reasoning in Walker $V$ will be discussed infra Part I.C.

49. This history of segregation in Dallas reaches back many generations, but the years of concern to the litigation spanned from 1950 into the late 1990s, when the DHA became a cooperating defendant. The first thirty-nine years are documented by the district court in Walker III, $734 \mathrm{~F}$. Supp. $1289,1294-1309$ (N.D. Tex. 1989). Subsequent years of defiance and obstruction of court orders are documented in Walker 10/6/97 Written Opinion, 1997 WL 33177466, at *8-17.

50. Issues of liability and remedy were before the lower court from 1985 to 1996. This period includes: the filing of the case in 1985, the issuance of a consent decree in 1987, the vacating of the 
Fifth Circuit's decision, this section discusses that history of resistance to housing integration by Dallas municipal actors.

A 1989 lower court decision in the Walker litigation recounted a history of deliberate segregation and discrimination in Dallas public housing. ${ }^{51}$ Tellingly, the court called it a history of "Not in My Neighborhood" activism to exclude black residents from white neighborhoods. ${ }^{52}$ The lower court defined a first phase of post-war segregation by the DHA, from 1950 to 1962 , characterized by growing free market demand for sale and rental housing among black residents. ${ }^{53}$ Fearing that this demand would lead to encroachment on white neighborhoods (and referring to it as "the Negro Housing Problem"s4), the city council and housing authority determined that Dallas would need alternate black housing in order to preserve the separation of the races. ${ }^{55}$ The city council therefore instructed the DHA to construct a 3,500-unit, explicitly segregated public housing project in West Dallas to meet black housing demand and prevent the expansion of black neighborhoods within the city. ${ }^{56}$ Despite the stigma, lack of services, environmental pollution, and lack of security which kept occupancy low in the white and Hispanic sections of the sprawling project, black population growth and racial harassment by whites in central Dallas kept black occupancy of West Dallas high. ${ }^{57}$

In 1962, after a campaign threatening racial integration through public housing, the Dallas City Council endorsed a referendum opposing any new construction of public housing in the city. ${ }^{58}$ The referendum passed, and construction of any new low-income public housing halted for seventeen years. ${ }^{59}$ In its existing properties, the DHA openly continued to assign tenants to neighborhoods based on race until 1965, when it switched to a masked but identical system of racial assignment policies that left white projects $100 \%$ white. $^{60}$ In 1967 , HUD outlawed such tenant assignment

\footnotetext{
consent decree in 1992 due to repeated violations, a new trial on the issue of remedies in 1994, and issuance of final remedial orders against the DHA in 1995 and HUD in 1996. Walker V, 169 F.3d at 976-78. The district court judge determined that race-conscious provisions were necessary for a meaningful remedy in 1995 and 1996, following trial on the issue. Walker 10/6/97 Written Opinion, 1997 WL 33177466 , at $* 10$ (discussing the court's reasoning for turning to race-conscious remedies).

51. Walker 111,734 F. Supp. at 1294-1309.

52. Id. at 1294.

53. Id. at 1294-96.

54. Id. at 1295 .

55. Id. at 1293-96. To inform the council's decision, in 1950 the Dallas Chamber of Commerce and other groups issued a "Joint Report on Negro Housing" in which they found that the "the only satisfactory and permanent solution to this problem can be realized where there is racial segregation." 1d. at 1295 .

56. Id. at 1294-96.

57. Id. at 1296 .

58. Id.

59. Id. at 1296-97.

60. Id. at 1297 .
} 
systems under Title VI, and, in the face of staunch resistance in Dallas to compliance with fair housing laws, HUD deferred all funding for new DHA projects until $1974 .^{61}$ According to the court, this resulted in the forfeiture of $\$ 31$ million in federal funds for modernization, new construction, and necessary maintenance of the sprawling West Dallas project "because the DHA Board refused to try to end racial segregation in public housing in Dallas." 62 DHA launched a mobile voucher program in 1975, but refused to honor these vouchers in the white suburbs of Dallas, despite advice from its own legal counsel that such conduct violated DHA's constitutional duty to correct its past discriminatory practices. ${ }^{63}$

By 1975 , when the boycott of federal fair housing laws had ended and federal funding resumed, the West Dallas project of 3,500 apartments had gone more than ten years with no maintenance or rehabilitation and had become almost entirely black. ${ }^{64}$ Soaring rates of crime, vacancy, and lead poisoning endangered and deeply stigmatized residents. ${ }^{65}$ In a perverse turn of public opinion stemming from the dangerous and dilapidated conditions of West Dallas, white opposition to any demolition of the projects began to mount for fear that displacement would lead to an influx of black families returning to central and suburban Dallas. ${ }^{66}$ In 1978 and the years following, the suburbs and the city of Dallas refused to fund any relocation housing for West Dallas residents. ${ }^{67}$ White opponents of relocation housing began to assert that status quo segregation was in the best interests of West Dallas tenants, claiming that proposed housing sites in white areas would provide inadequate facilities for the poor and increase crowding in local schools. ${ }^{68}$ In addition, opponents emphasized a theme that would later convince the Fifth Circuit: the DHA was incompetent to maintain housing properly, which would lead to physical deterioration and increased crime rates. ${ }^{69}$

By 1989 , when the lower court issued its race-conscious remedial order, the DHA had still failed to meet its commitments to build new housing in "non-minority impacted areas" (as if race itself was a negative impact). ${ }^{70}$ Opposition to construction of any new public housing in Dallas remained fervent throughout the governance of the 1987 consent decree, yet by later

61. Id. at 1298 .

62. Id. (emphasis in original).

63. Id. at 1300. This was no doubt sound advice. In 1976, the Supreme Court upheld a lower court finding that a metropolitan-scale integration plan was necessary to remedy unconstitutional segregation similar to that in Dallas. Hills v. Gautreaux, 425 U.S. 284, 298-300 (1976). See discussion infra Part 11.A.

64. Walker III, 734 F. Supp. at 1306 \& n.56.

65. Id. at 1307 .

66. Id. at $1311 \&$ n.67.

67. Id. at 1301 .

68. Id. at 1301-02.

69. Id. at 1302. Cf. Walker V, 169 F.3d 973, 980 (5th Cir. 1999).

70. Walker III, 734 F. Supp. at 1302-03. 
years, opponents had a race-neutral rationale: the criminality and social distress of the occupants of West Dallas. ${ }^{71}$ Segregation had created a monument to perceptions of racial inferiority which then fueled rational, and ostensibly race-neutral, opposition to integration. That cycle-segregation and racial discrimination creating communities of severe distress and isolation, thereby generating a race-neutral rationale for excluding their residents-is the key insight from the history of neighborhoods like West Dallas in the context of emerging colorblindness jurisprudence in residential segregation cases.

\section{The Fifth Circuit Decision}

It was into this cycle of segregation perpetuated by racial prejudice and reinforced by its social effects that in 1999, the Fifth Circuit held that the race-conscious aspects of the lower court's remedial order violated the white homeowners' equal protection rights. ${ }^{72}$ The court reasoned that the provisions directing the DHA to locate new, site-based public housing in predominantly white neighborhoods were not narrowly tailored to achieve their purpose of remedying the "effects of past discrimination." 73 For both the lower court and the Fifth Circuit, the explicit remedial goal was thus movement of "black families into white areas,"74 if not integration of public housing into the larger metropolitan fabric of the city. However, the court disagreed with the lower court that race-neutral remedies (such as mobile housing vouchers to relocate tenants of segregated developments) needed to be combined with race-conscious provisions (such as construction or acquisition of new housing units in white neighborhoods) in order to remedy Dallas public housing's "sordid tale" of racial discrimination and segregation. ${ }^{75}$

Walker $V$ has several characteristics that may signify future directions in a colorblind understanding of equal protection injuries, interests, and remedies. Each characteristic will be discussed in this section. First, the circuit cursorily recognized standing on the basis of an injury that was

71. See id. at 1298-1313 (discussing the changing justification for resistance to public housing over time).

72. Walker $V, 169$ F.3d at 987.

73. Id. at 984. The circuit alternates usage of this language with the phrase "vestiges of past discrimination and segregation." See, e.g, id. at 981 . However, curing "effects" and "vestiges" of discrimination imply different goals: the former suggests integration of segregated neighborhoods as an indefinite remedy, while the latter might suggest the goal of nondiscrimination as a remedy for what minimal prejudice might remain.

74. The opinion uses this phrase and variations of it as a substitute for the language of "integration." See, e.g., id. at 985 . Perhaps the court conceived of the latter formulation of the remedial project in the Walker litigation as too extensive a commitment, i.e., it disavowed a city-wide cure for neighborhood segregation entrenched by public housing, choosing instead to frame its goals as the movement of finite numbers of individual families within Dallas.

75. Id. at 976 . 
premised on segregation and discrimination. Second, the defendants conceded the compelling state interest prong of the strict scrutiny test, a move that strategically buried the government's interest in remedying segregation for the African-American plaintiffs. Third, the narrow tailoring requirement, the second prong of the strict scrutiny test, launched a reconsideration of the lower court's factual findings on the issue of remedies and an inquiry into hypothetical policy alternatives. A fourth and final characteristic underpins the circuit's analysis of standing as well as its application of strict scrutiny: the decision reflected confidence that the relevant state actors, who had recently begun cooperating with the lower court's remedial orders, wcre no longer affected by racial bias and thus were capable of achieving remedial integration goals under a race-neutral order. Taken together, these characteristics constitute a generous reading of the homeowners' reverse discrimination claim that maps a new outer boundary in colorblindness jurisprudence.

In upholding the white homeowners' standing to sue under the Fourteenth Amendment, the Fifth Circuit recognized the homeowners' alleged twofold injury: (1) purposeful discrimination based on race, and (2) the threat of "specific" injury, including "decreased property values, increased crime and population density, environmental problems, and diminished aesthetic values of the neighborhood. ${ }^{176}$ The court determined that a "stigmatizing injury" satisfied the injury requirement of standing doctrine" and held that the "remedial order's explicit racial classification alone is sufficient" to create a stigmatizing injury. ${ }^{78}$ As to the threat of specific injury, the court stated simply that the district court judge "was well aware of the potential for neighborhood disruption traceable to improperly managed public housing projects," and that no cases on the same specific issue had asserted a result to the contrary. ${ }^{79}$ The decision also found an adequate line of causation between the allegedly unconstitutional conduct (the race-conscious remedial order) and the injury (the selection of the site adjacent to the homeowners) despite the protestations of HUD and the DHA that the site was selected based on numerous other race-neutral criteria. $^{80}$

The court found it irrelevant whether the homeowners could identify a "similarly situated set of black persons who had been treated better." ${ }^{81}$ The

\footnotetext{
76. Id. at 979.

77. $1 d$.

78. Id. For a discussion of the contrasting treatment of white and black plaintiffs in conducting injury analysis for standing purposes, see Gene R. Nichol, Standing for Privilege: The Failure of Injury Analysis, 82 B.U. L. REv. 301 (2002) (arguing that, functionally, standing law privileges majoritarian interests).

79. Walker $V, 169$ F.3d at 980.

80. Id. at $980-81$.

81. Id. at 981.
} 
facial racial classification of the order was found sufficient to "establish unequal treatment by [its] very nature." ${ }^{82}$ Given the density of public housing in black neighborhoods of Dallas, the use of the words "unequal treatment" here is nonsensical. As the lower court had demonstrated, and the Fifth Circuit accepted, white households (whether housing authority tenants or homeowners) had always been privileged in the siting and services of public housing. The court's use of "unequal treatment" strictly in prospective terms ignored the context of the case, namely the past constitutional violations which had shaped the contours of the remedial order. As a result, the ruling privileged white homeowners to be free from the same injuries caused by mismanaged, concentrated public housing that black homeowners had long endured.

The court's rationale for finding a specific injury was stated as a matter of common knowledge: public housing neighborhoods are disruptive, dangerous, and detrimental to property values. Yet these very conditions of concentrated public housing neighborhoods, in Dallas as elsewhere, are linked to segregation and racial discrimination. ${ }^{83}$ Walker $V$ ignored or dismissed the particular attributes of the proposed buildings: their small scale, the presence of other buildings of similar size under private management, and the special credentials of the tenants eligible to live in the proposed site. The court premised its finding of specific injury on the assumption that negative social conditions attach to public housing residents, even when they locate in more stable neighborhoods with greater resources, rather than result from concentrated conditions of poverty and estrangement from educational and economic opportunity. In the face of a shameful record of public housing management which had caused incalculable suffering among black residents (including criminal victimization, stigmatization, and illegal housing conditions), the Fifth Circuit decision nevertheless demonstrated imbedded prejudices about criminality and negative neighborhood values in Dallas's inner-city community that were not unlike the fear and prejudice which fueled the creation of West Dallas. It is a decision written from the perspective of the white household which, without racial animus, wants to avoid what it believes are the social conditions of public housing residents, even if that avoidance conflicts with those public housing residents' equal protection rights.

The second most significant characteristic of the Walker $V$ decision is that the court never named the compelling state interest at stake in the litigation. The homeowner plaintiffs had conceded the state's interest, and

82. Id.

83. A wave of sociological research launched by the Kerner Commission Report in 1967 explained the extreme distress in American inner city neighborhoods and its relationship to segregation and discrimination. For recent examples, see MASSEy \& Denton, supra note 27; Wilson, The Truly Disadvantaged, supra note 26; John Charles Boger, Race and the American City: The Kerner Commission in Retrospect-An Introduction, 71 N.C. L. REv. 1289 (1993). 
the court never articulated what it might have been. ${ }^{84}$ The compelling government interest can be surmised, however, as one of two possibilities: racial integration (residential diversity per se) or direct remediation of the harms of segregation experienced by the black plaintiffs. ${ }^{85}$ The plaintiff homeowners made a strategic decision not to name or contest either of these interests, thus avoiding the clash between their equal protection rights and those of the black plaintiffs, or other future Dallas residents affected by housing authority policy. The Fifth Circuit acknowledged that " $[t]$ he history of public housing in Dallas is a sordid tale of overt and covert racial discrimination and segregation," 86 but, with no state interest contested, the circuit never had to state that precisely this sordid history had led to the lower court's remedial order. The homeowners and the circuit focused instead on attacking the remedial order as not narrowly tailored.

Functionally, the Fifth Circuit employed the narrow tailoring prong of the strict scrutiny test to contest the lower court's factual findings on the issue of remedy. On the basis of a series of hypothetical policy changes that the housing authority might make, the court found that the district court had not exhausted race-neutral remedies before turning to a "last-resort" measure. ${ }^{87}$ The court assumed that the discriminatory practices of the DHA, HUD, and the city of Dallas were "now-past," knowledging the substantial body of evidence that, absent such a remedial order, the agencies would remain unwilling - or politically unable — to site public housing outside of low-income minority communities. ${ }^{89}$

The court hinged its optimism about alternate, race-neutral paths to desegregation on the promise of mobile "Section 8 " housing vouchers to desegregate the metropolitan area by dispersing public housing tenants. ${ }^{90}$ In a laudatory discussion of the potential of housing vouchers, the decision emphasized cost-efficiency, the promise of the market, and personal prefcrence. ${ }^{91}$ Despite an extensive body of evidence documenting the numerous ways that vouchers alone would be inadequate to remedy the severe, entrenched segregation of the Dallas housing market, the court refused to

84. Walker $V, 169$ F.3d at 982.

85. Perhaps the homeowners did not contest this fact because either of these two interests might have had traction. The subsequent Supreme Court decision in Grutter v. Bollinger, $123 \mathrm{~S}$. Ct. 2325 (2003), confirms that some space remains in equal protection doctrine for state interests in diversity. For discussion of the viability of this latter remedial interest, see infra Part ll.A.

86. Walker $V, 169$ F.3d at 976 .

87. Id. at $981-87$.

88. Id. at $981-82$.

89. The opinion in Walker I provides a catalogue of the DHA's failures to implement the provisions of the consent decree. Walker I, 734 F. Supp. 1231, 1234-46 (N.D. Tex. 1989).

90. Walker $V, 169$ F.3d at 983 . Section 8 vouchers help low-income households afford rental accommodations on the private market by subsidizing a portion of their rent. The "Section 8 " name refers to the origin of rental assistance, Section 8 of the National Housing Act of 1937. Paul Boudreaux, Vouchers, Buses, and Flats: The Persistence of Social Segregation, 49 VILL. L. REv. 55, 71-72 (2004).

91. Walker $V, 169$ F.3d at 983-84. 
make a factual finding on the issue. ${ }^{92}$ Yet it nevertheless made the generalized factual findings that the voucher program was "increasingly successful in moving black families into white areas," and that the DHA and HUD could make it even more successful with increased funding and other changes. ${ }^{93}$ These policy suggestions, which would require major budgetary changes, were beyond the scope of the district court to enact in hearing the case on remand.

As for site selection for new project-based public housing, the court insisted that race-neutral site selection was possible, while still meeting the goals of the district court to disperse public housing, through race-neutral preferences such as a low poverty rate and low density of public housing. ${ }^{94}$ One need look no further than the lower court opinion to see that the Fifth Circuit's optimism ignored the evidentiary record: due to deliberate racial segregation, the DHA had never in its history located a non-elderly, majority black public housing project in a predominantly white area. ${ }^{95}$

To reach the conclusion that race-neutral orders were a viable means of remedying the harms of over fifty years of purposeful segregation by the DHA, the court relied on unbending confidence that the DHA and the city had become colorblind decision makers in the seven years since their last constitutional violation. ${ }^{96}$ In making this leap of faith, the court shifted the focus of the municipal actors' remedial obligations by orienting their corrective efforts towards class (i.e., the use of benchmarks for compliance based on neighborhood poverty rates) rather than race, even though socioeconomic discrimination was not at issue in the case. ${ }^{97}$ This shift belied the factual record's indication that race, not class, explicitly drove the DHA's systemic concentration of public housing for minority households in nonwhite, high-poverty neighborhoods and white public housing in white neighborhoods. ${ }^{98}$ Nevertheless, the court declared that class diversity criteria for site selection, implemented by supposedly reformed actors, could remedy this race-driven system of discrimination. ${ }^{99}$

As a result of the Fifth Circuit's decision, the DHA stayed construction at sites adjacent to the plaintiff homeowners until the district court

92. Id. at 984 .

93. See id. at $984-85$.

94. Id. at 985.

95. See Walker I, 734 F. Supp. 1231 (N.D. Tex. 1989); Walker Il, 734 F. Supp. 1272 (N.D. Tex. 1989); Walker III, 734 F. Supp. 1289 (N.D. Tex. 1989). These opinions summarize the persistent, historic failure of the DHA to comply with federal fair housing laws and promote integration of its public housing neighborhoods.

96. The circuit stated, "DHA, HUD, and the City of Dallas no longer discriminate against black families in DHA's public housing programs." Walker V, 169 F.3d at 985.

97. And of course, a claim of discrimination against a low-income neighborhood with a high density of public housing would not succeed under the Equal Protection Clause. See San Antonio Indep. School Dist. v. Rodriguez, 411 U.S. 1 (1973).

98. Walker $V, 169$ F.3d at 976.

99. Id. at 985 . 
held additional hearings and entered a revised, race-neutral remedial order. ${ }^{100}$ Due to the homeowners' sustained opposition and their legal victory in 1999, development has been on hold since the DHA purchased the land in 1996. In December 2003, the DHA requested the district court's permission to carry out its plans for the site, arguing that the property satisfied criteria approved by the Fifth Circuit. ${ }^{101}$ The homeowners continue to contest any development on the site, relying on the Fifth Circuit decision as an absolute bar. ${ }^{102}$

Despite a split with the Second Circuit, the Supreme Court denied certiorari on the issue in 2000 and 2001, making the immediate implications of Walker $V$ limited to its jurisdiction. ${ }^{103}$ Yet the decision signals new directions in colorblindness jurisprudence that pose significant changes for residential desegregation litigation, and, by implication, other forms of court-ordered remedial diversity.

Il

The Colorblindness Frontier: Curtailing Desegregation

The Walker $V$ decision signifies a new frontier in colorblindness jurisprudence: the viability of reverse discrimination claims as a barrier to remedying the harms of unconstitutional segregation. Though facially neutral, the application of colorblindness doctrine in this context enables certain neighborhoods to exclude racially dissimilar public housing, thus perpetuating their resistance to racial integration. This Part will discuss the meaning and contours of this new paradigm in colorblindness, as charted by Walker $V$ 's interpretation of equal protection rights and remedies in juxtaposition with other equal protection cases.

Walker V's expanded form of colorblind jurisprudence has several major characteristics and implications for equal protection doctrine, each of which will be discussed below. First, it advances the frontier of strict scrutiny of racial classifications into the realm of remedial orders for judicially determined constitutional violations-taking it beyond the scope of Supreme Court precedent on remedial orders by other state actors and boldly bypassing Supreme Court precedent in the residential desegregation context. Second, Walker $V$ 's colorblind regime subverts one set of plaintiffs' equal protection rights in the face of a competing equal protection claim by a second set of plaintiffs. Third, it makes the narrow tailoring requirement of the Equal Protection Clause fatal in fact, because, in the name

\footnotetext{
100. Id. at 987 .

101. See Horner, supra note 16.

102. Id.

103. Walker v. City of Mesquite, 528 U.S. 1131 (2000), denying cert. to Walker V, 169 F.3d 973; City of Yonkers v. United States, 534 U.S. 1054 (2001), denying cert. to United States v. Sec'y of Hous. \& Urban Dev., 239 F.3d 211 (2001).
} 
of narrow tailoring, a court cannot employ race-conscious remedies even where race-neutral remedies have proven untimely, impractical, or unaccountable to remedial goals. Finally, and very significantly to the housing policy context, a Walker $V$ regime would effectively increase the involvement of non-state actors in implementing equal protection remedies, though such actors are themselves unreachable by the Fourteenth Amendment. Together, these characteristics signify a bold extension of reverse discrimination law, marking a more restrictive boundary on courts' ability to remedy preceding constitutional civil rights violations against plaintiffs of color.

\section{A. Restraining Courts' Remedial Authority Under the Fourteenth Amendment}

Under the colorblind segregation regime of Walker $V$, judicial remedies for explicit, race-conscious segregation must be race neutral to avoid an application of strict scrutiny analysis. This represents two dramatic changes from the Supreme Court's equal protection jurisprudence: a colorblindness mandate is applied to courts charged with remedying racial discrimination, and, as a corollary, per se racial integration is declared an unconstitutional remedy for per se racial segregation. At stake in the first of these extensions is judicial authority to determine the contours of equitable relief for a constitutional violation-arguably an authority of a different nature than legislative or other governmental efforts to remedy past discrimination. At stake in the second extension is the power of courts to seek diversity as a remedy for segregated social structures caused by explicit, unconstitutional racial discrimination. Colorblind segregation doctrine thus pushes past the outer boundaries of Court doctrine in reverse discrimination cases, rejecting Court precedent on the constitutionality of remedial integration measures crafted by judges.

The Supreme Court has never held that strict scrutiny applies to raceconscious remedies issued by courts. ${ }^{104}$ In United States $v$. Paradise, the Court addressed the constitutionality of a race-conscious order issued by a district court without resolving the issue of what level of scrutiny should apply. ${ }^{105}$ Deeming that the order in question survived even strict scrutiny, the Court upheld a remedial order to integrate a defiant police department following extensive revelations of employment discrimination. ${ }^{106}$ The Court emphasized the special deference due to a lower court (implicitly

104. In Adarand Constructors, Inc. v. Pena, the Supreme Court mandated the application of strict scrutiny to government efforts to redress legislatively determined discrimination. 515 U.S. 200, 206, 227 (1995). In the public housing context, the Adarand holding would thus reach a proactive integration program launched internally by a city council or housing authority to remedy effects of past segregationist policies.

105. 480 U.S. 149 (1987).

106. Id. at 153-67, 185-86. 
distinguished from a legislature) in determining effective remedial measures for a preceding constitutional violation. ${ }^{107}$ It articulated that the judicial order in the case was "supported not only by the governmental interest in eradicating [the police department's] discriminatory practices, it is also supported by the societal interest in compliance with the judgments of federal courts." 108 In a concurring opinion, Justice Stevens was even more explicit about the special difference between race-conscious acts by legislatures and judges, declaring that those by judges need not overcome the "strong presumption" against race-conscious decisions when they are faced with a governmental party guilty of unconstitutional discrimination. ${ }^{109} \mathrm{He}$ stated unequivocally: "The relief that a district judge has a duty to fashion must unavoidably consider race" 110 in cases to "vindicate federal constitutional guarantees." 111 Implicit in the Court and Justice Stevens's concurring analysis in Paradise is the recognition that two sets of constitutional rights are at stake in challenges to remedial orders designed to redress constitutional violations. ${ }^{112}$

In Yonkers, a Second Circuit decision evaluating the constitutionality of a race-conscious remedial order in the litigation, the court stated that under Adarand and Paradise, strict scrutiny might not apply to "race-based remedies ordered by 'a district judge who has found that a governmental unit before him is guilty of racially discriminatory conduct. $" 113$ Noting the necessity of Justice Stevens's "fifth vote to affirm a court-ordered race-based remedy," the Second Circuit suggested that the Court may have already ruled on the heightened deference due where a district court judge had deemed race-consciousness necessary to remedy the constitutional violation found in his or her own court. The Yonkers decision acknowledged Adarand's broad language subjecting race-conscious government decisions to strict scrutiny, but reasoned that the case left open the question of racebased remedies adopted by courts. ${ }^{114}$ Indeed, Adarand's explicit focus on

107. The Court spoke of the "respect owed" to a lower court's determination that the relief in question was necessary to remedy a Fourteenth Amendment violation, noting that such a court has "'not merely the power but the duty to render a decree which will so far as possible eliminate the discriminatory effects of the past as well as bar like discrimination in the future."' $I d$. at 183 (quoting Louisiana v. United States, 380 U.S. 145, 154 (1965)).

108. Id. at 170.

109. Id. at 193-94.

110. Id. at 194 (Stevens, J., coneurring).

111. Id. at 194-95 (Stevens, J., concurring).

112. See infra Part II.B.

113. United States v. Sec'y of Hous. \& Urban Dev., 239 F.3d 211, 218 (200I). It is interesting to note the integration progress made in Yonkers, New York, following the litigation leading up to and including the Second Circuit's decision. See Xavier de Souza Briggs et al., In the Wake of Desegregation: Early Impacts of Scattered-Site Public Housing on Neighborhoods in Yonkers, New York, J. AM. PlanNing Ass'N (1999), http://www.huduser.org/publications/pdf/wake.pdf.

114. Sec'y of Hous. \& Urban Dev., 239 F.3d at 218 (citing Adarand Constructors, Inc. v. Pena, 5I5 U.S. 200, 227). 
"government" 115 and its articulated purpose to extend strict scrutiny to acts by Congress and the federal government, ${ }^{116}$ obscured whether the decision covered court orders. In contrast to Walker $V$, which never mentioned the Paradise distinction between judicial and legislative decision makers, nor the uncertain reach of Adarand on this point, ${ }^{117}$ the Second Circuit's reasoning acknowledges the unsettled terrain of a colorblind judiciary in civil rights cases.

Distinguishing judicial remedies from remedies crafted by other bodies is supported by the Court's own rationales for imposing strict Iimits on race-conscious remedial programs. In restricting the power of legislative and other governmental bodies to remediate racial discrimination with race-conscious measures, the Court has emphasized diffuse culpability for past discrimination, ${ }^{118}$ the disconnect between measures for redress and past violations, ${ }^{119}$ and the risk of capture by divisive "racial politics." ${ }^{120} \mathrm{By}$ contrast, a judicially ordered remedy responds to a specific set of plaintiffs (rather than an undifferentiated public) whose case of wrongful discrimination has been proven to the satisfaction of the court's constitutional judgment. Further, judicial remedies-determined as equitable relief through an arguably apolitical judicial process-are targeted to a specific set of facts and culpable actors before the court. A majority on the Court may indeed recognize a distinction between race consciousness employed by courts and other government institutions. Justice Scalia's concurrence in Richmond v. Croson acknowledged the space created in Paradise for race consciousness in judicial remedies. ${ }^{121}$

In the context of housing desegregation litigation, such remedial flexibility may be especially important, since courts must often compel

115. The Court used broad language of "whatever federal, state, or local government actor," but in the next breath, it distinguished courts from government, writing: "[b]y requiring strict scrutiny of racial classifications, we require courts to make sure that a governmental classification based on race ... is legitimate ...." 515 U.S. at 227-28.

116. Id. at $222,229$.

117. Walker $V$ announces the application of strict scrutiny, citing Adarand, with no mention of what Paradise might indicate on this point. See Walker V, 169 F.3d 973, 981 ( $5^{\text {th }}$ Cir. 1999).

118. See City of Richmond v. J.A. Croson Co., 488 U.S. 469, 480 (1989) (emphasizing the absence of direct evidence demonstrating racial discrimination specifically by the defendant city); See also Adarand, 515 U.S. at 222 (citing Croson to make a similar point).

119. Croson, 488 U.S. at 500-07 (arguing that the absence of racial integration in the industry at issue was a "generalized assertion" that did not provide an adequate basis for remedial action).

120. Id. at 493 ("Absent searching judicial inquiry into the justification for such race-based measures, there is simply no way of determining what classifications are 'benign' or 'remedial' and what classifications are in fact motivated by illegitimate notions of racial inferiority or simply racial politics.").

121. Id. at 521 (Scalia, J., concurring) ("And we have permitted federal courts to prescribe quite severe, race-conscious remedies when confronted with egregious and persistent unlawful discrimination."). 
governmental bodies to act against the racial politics of their locality. ${ }^{122}$ For instance, in the Walker case, the DHA expressed appreeiation for the persistence of the plaintiffs (and implicitly, the court) in enforcing the authority's remedial obligations. One study of the litigation documented that:

[d]espite the contentious nature of the case, the DHA credits [improvements in its organization] in large part to the effect of continuous monitoring by the plaintiffs' attorney. The plaintiffs' attorney has been tenacious in holding the DHA to the terms of the decree and in ensuring that Walker provided genuine desegregative opportunities for DHA tenants. ${ }^{123}$

Thus, the Court's concern in Croson about a "politics of racial hostility" is especially relevant where local resistance makes implementation of remedial desegregation orders slow and contentious.

In addition to instructive Supreme Court precedent on race-conscious remedial efforts generally, the Court has spoken specifically on the issue in the housing desegregation context. In Hills $v$. Gautreaux, the Court evaluated a race-conscious remedial order to redress unconstitutional segregation perpetuated by the Chicago Housing Authority. ${ }^{124}$ In a decision emphasizing the lower court's discretion to determine equitable relief, the Court upheld the integration remedy. ${ }^{125}$ Furthermore, the decision wrestled with the difficulty of providing "an effective remedy for the racially segregated public housing" that was "wholly commensurate with the "nature and extent of the constitutional violation." "126 In contrast to the Fifth Circuit's analysis, the Court determined that such relief would need to facilitate immediate integration across the city's racial and jurisdictional boundaries. ${ }^{127}$

The factual history in Gautreaux's Chicago mirrored the Dallas story in all material respects. In the words of the Seventh Circuit, the Chicago Housing Authority "stripped thousands of residents of the [c]ity of Chicago of their Fifth and Fourteenth Amendment rights for a score of years," a

122. A national investigation into the implementation of desegregation consent decrees demonstrated the powerful barrier posed by local resistance to incoming public housing and desegregation orders. See 1 Susan J. Popkin Et al., U.S. Dep't of Hous. and Urban Dev., Baseline Assessment of Public Housing Desegregation Cases: Cross-site Report 73-78 (2000). Desegregation cases spanning the thirty-five years since the passage of the Fair Housing Act provide evidence of the origins of such resistance in racial fear and prejudice. See discussion, infra Part III.

123. 2 Susan J. Popkin et al., U.S. Dep't of Hous. and Urban Dev., Baseline Assessment of Public Housing Desegregation Cases: Case Studies 3-64 (2000).

124. 425 U.S. $284,286-88$ (1976).

125. The Court wrote that "“[o|nce a right and a violation have been shown, the scope of the district court's equitable powers to remedy past wrongs is broad, for breadth and flexibility are inherent in equitable remedies." 'Id. at 297 (quoting Swann v. Charlotte-Mecklenburg Bd. of Ed., 402 U.S. 1, 15 (1971)).

126. Id. at 300 (quoting Milliken v. Bradley, 418 U.S. 717, 744 (1974)).

127. Id. at $298-300$. 
history that demonstrated "a callousness on the part of the appellees towards the rights of the black, underprivileged citizens of Chicago that is beyond comprehension." 28 The district court found that the city and housing authority had deliberately chosen public housing sites to enforce residential segregation in the city in violation of the plaintiffs' equal protection rights under the Fourteenth Amendment. ${ }^{129}$ The court ordered the housing authority to build its next 700 new units in predominantly white neighborhoods in Chicago. ${ }^{130}$ Due to extensive white exodus from the city of Chicago and years of resistance to desegregation by the city and housing authority, the Seventh Circuit ordered on remand the adoption of a remedial integration plan to encompass the entire Chicago metropolitan area, including its suburbs. ${ }^{131}$ That latter remedy, drafted by the circuit in explicitly and dramatically integrationist terms, ${ }^{132}$ was upheld by the Supreme Court. ${ }^{133}$

In contrast to Walker $V$, the opinion of the Supreme Court in Gautreaux did not focus on the implicit or explicit rights of white Chicago residents to be free from public housing. The focus of the decision was appropriately on the victims of segregation: African-American households that were systematically isolated and confined into neighborhoods already crowded with the racially subordinated urban poor. ${ }^{134}$ Rather than order a remedy confined to the Chicago city limits to reflect the housing authority's jurisdiction, the Court held that the remedy must expand housing choice for black families into the city's predominantly white suburbs. ${ }^{135}$ As such, the decision implicitly focused on future integration as the necessary remedy for past exclusion. The Court found that "[ $t]$ he relevant geographic area for the purposes of the respondents' housing options is the Chicago housing market, not the Chicago city limits."136 Evidence of suburban

128. Gautreaux v. Chi. Hous. Auth., 503 F.2d 930, 932 (7th Cir. 1974).

129. Gautreaux v. Chi. Hous. Auth., 296 F. Supp. 907, 909-13 (N.D. 1ll. 1969), aff'd, 436 F.2d 306 (7th Cir. 1970).

130. Gautreaux v. Chi. Hous. Auth., 304 F. Supp. 736, 738 (1969); see also Gautreaux, 503 F.2d at 933 .

131. Gautreaux, 503 F.2d at $936-39$.

132. Id. The court wrote: "[D]efendants' discriminatory site selection within the [c]ity of Chicago may well have fostered racial paranoia and encouraged the 'white flight' phenomenon which has exacerbated the problems of achieving integration to such an extent that intra-city relief alone will not suffice to remedy the constitutional injuries." Id. at 940 .

133. Hills v. Gautreaux, 425 U.S. 284, 286 (1970).

134. Chicago's black neighborhoods were already crowded with the urban poor, many of whom had moved north during the Great Migration to follow industrial jobs, and all of whom faced exclusion and segregation in education and employment. See Hirsch, supra note 28 (discussing the history of local and federal policies which led to black ghettoization in Chicago public housing); STEPHEN GRANT Meyer, as long as They Don't Move Next Door: Segregation and Racial Conflict in AMERICAN NEIGHBORHOODS 30-47 (2000) (describing the history of the Great Migration and the discrimination which faced blacks upon arrival in the North).

135. Gautreaux, 425 U.S. at 299.

136. Id. 
discrimination, as well as evidence suggesting an "“extra-city impact' of the petitioner's 'intra-city discrimination," 137 demonstrated to the Court that an equitable remedy had to extend beyond city limits. ${ }^{138}$ The raceconscious, metropolitan-scale remedy upheld by the Court thus recognized the interconnectedness of the urban housing market, with beneficiaries as well as victims of segregation. ${ }^{139}$ Such a regime acknowledged the need for an integration strategy that was not confined to the samc jurisdictional lines that had previously mapped segregation.

After recognizing the white Chicago suburbs as complicit in, even beneficiaries of, discrimination and exclusion of public housing, the Court made the whiteness of Chicago's suburbs central to its remedy for racial segregation: "An order directing HUD to use its discretion under the various federal housing programs to foster projects located in white areas of the Chicago housing market would be consistent with and supportive of well-established federal housing policy." 140 The Gautreaux framework has been praised as an appropriate model of judicial involvement in housing desegregation, and the Gautreaux Assisted Housing Program, which stemmed from the Supreme Court decision, ${ }^{141}$ has been deemed a model for residential, racial, and economic integration of low-income black families into white suburbs. ${ }^{142}$

With its focus on a race-conscious antidiscrimination remedy, rather than a colorblind nondiscrimination remedy, Gautreaux preceded a generation of reverse discrimination cases decided favorably by the Supreme Court. ${ }^{143}$ Yet the Walker $V$ court was too quick to dismiss the case as irrelevant, if not moot. It only referenced the decision once, in a footnote, noting that "Hills [v. Gautreaux] predates significant changes that have occurred both in HUD's approach to public housing and in the scrutiny afforded race-conscious remedies." 144 On the contrary, Gautreaux, like Paradise, is significantly distinct from the reverse discrimination lineage cited by the Fifth Circuit in Walker $V$, because it considers a lower court's remedial order to redress systemic constitutional violations, not a legislative program to achieve intcgration. And of course, Gautreaux remains

\footnotetext{
137. Id. at 292.

138. Id.

139. For an exceptional discussion of such interdependence, see David Dante Troutt, Ghettoes Made Easy: The Metamarket/Antimarket Dichotomy and the Legal Challenges of Inner-City Economic Development, 35 HARV. C.R.-C.L. L. REV. 427, 429-32 (2000) (describing the relationship of the middle class "metamarket" to the segregated urban underclass "antimarket").

140. Gautreaux, 425 U.S. at 301.

141. See, e.g., Hendrickson, supra note 28, at 58-65.

142. See, e.g., Leonard S. Rubinowitz \& James E. Rosenbaum, Crossing the Class and Color Lines: From Public Housing to White Suburbia (2000).

143. See, e.g., Adarand Constructors, Inc. v. Pena, 515 U.S. 200 (1995); Shaw v. Reno, 509 U.S. 630 (1993); City of Richmond v. J.A. Croson Co., 488 U.S. 469 (1989).

144. Walker V, 169 F.3d 973, 983 n.20 (5th Cir. 1999), cert. denied, 528 U.S. 1131 (2000)
} 
standing precedent buttressed by Paradise, instructing that race-conscious remedial orders are permissible when necessary to correct a preceding constitutional violation. While Court doctrine remains ambiguous on the degree of scrutiny applicable to race-conscious remedial orders issued by a court, it nevertheless offers strong precedent that significant deference is due to judicial integration measures designed to redress the constitutional violation of segregation.

\section{B. The Lost Parties: A Collision of Equal Protection Rights}

Walker $V$ turned on the equal protection rights of white homeowners to be frce from classification by race, and the Fifth Circuit upheld their claim for colorblind treatment by the courts. Yet the circuit submerged and functionally displaced a different set of equal protection rights in awarding victory to the homeowners: the equal protection rights of the victims of Dallas's history of intentional racial segregation. The very state action at issue in Walker $V$ was a lower court order to remedy a systemic pattern of judicially determined Fourteenth Amendment violations, not a government action to proactively benefit racial minorities, nor a government program to remedy legislatively determined past harms. ${ }^{145}$ The circuit's finding that the white homeowners have the right to be free from classification based on race was made at thc expense of the black plaintiffs' rights to be free from similar, albeit implicit, classification. ${ }^{146}$

In addition to subverting the equal protection rights of the African-American plaintiffs, an unnamed category of people also suffered the same dignity and property injuries alleged by the white homeowners and recognized by the Walker $V$ court, though these lost parties had no avenue of constitutional redress. The residents of low-income African-American and Latino neighborhoods, where past public housing was disproportionately concentratcd under a race-conscious segregation regime, were also victimized by the race-based concentration of public housing and its correspondingly high rates of local poverty. ${ }^{147}$ The equal protection rights of these nonwhite actors were implicitly at stake in the lower court's remedial order. Finding that public housing was either built

145. By contrast, though the Fifth Circuit referred to both Adarand and Croson, the plaintiffs in those cases challenged non-judicial government action. See Adarand, 515 U.S. 200; Croson, 488 U.S. 469.

146. Michelle Adams identified another significant effect of the absence of an explicit discussion of the compelling state interest at issue in the Walker litigation: the discussion of narrow tailoring lacks accountability to the goal of racial classification. Adams, supra note 20, at 1147-49. See generally Darren Lenard Hutchinson, "Unexplainable on Grounds Other than Race": The Inversion of Privilege and Subordination in Equal Protection Jurisprudence, 2003 U. ILL. L. REv. 615 (2003) (arguing that the Court now protects historically privileged classes through equal protection jurisprudence).

147. The defendants in Walker $V$ alleged as much, arguing that there was no similarly situated set of nonwhite Dallas residents who had been treated better by the city council or the DHA. The circuit dismissed this argument as irrelevant. Walker $V, 169 \mathrm{~F} .3 \mathrm{~d}$ at 981 . 
in their neighborhoods or not built at all, the lower court reasoned that a race-conscious remedy specifying minimal construction in white neighborhoods was essential for taking the DHA out of the business of segregation. ${ }^{148}$ Though the Fifth Circuit acknowledged the siting of all public housing in minority areas of Dallas, ${ }^{149}$ the concession of a compelling state interest by the homeowner plaintiffs (discussed supra Part I.C) meant that these harms were never juxtaposed or seen as interdependent with the alleged constitutional violation of the race-conscious remedial order.

\section{Narrow Tailoring Becomes Fatal in Fact}

Even where strict scrutiny is applied to a judicial remedy for unconstitutional housing segregation, such measures may withstand review. Paradise indicates that such a remedy pursues a compelling state interest, clearly satisfying the first prong of strict scrutiny. ${ }^{150}$ Application of the second requirement, narrow tailoring, proved to be the crux of the divergence between the Fifth and Second Circuits in considering race-conscious remedies for housing segregation. In Walker $V$, the Fifth Circuit sidestepped the collision between white and nonwhite equal protection rights by determining that there were more narrowly tailored, race-neutral alternatives to remedy the constitutional harms of segregation - an interpretation that rendered the narrow tailoring requirement a constitutionally fatal quest for alternative social policies. By contrast, the Second Circuit found that a similar race-conscious order in the Yonkers litigation was a narrowly tailored approach to remedial desegregation. ${ }^{151}$ While narrow tailoring turns on case-specific facts, the circuits nevertheless applied discernibly different versions of narrow tailoring. Their disagreement turned on the question: how long must a court await meaningful steps towards court-ordered integration before mandating compliance through explicitly race-conscious benchmarks? Imbedded in this inquiry is a question of deference to district courts in their assessment of tolerable outer limits on delays and obfuscation by defendants.

In Adarand, the Supreme Court "dispel[led] the notion that strict scrutiny is "strict in theory, but fatal in fact." 152 The Supreme Court reasserted the scope of the narrow tailoring requirement in its recent decision

148. Walker 10/6/97 Written Opinion, No. 3:85-CV-1210-R, 1997 WL 33177466, *10 (N.D. Tex. Oct. 6, 1997) (memorandum opinion), rev'd in part, vacated in part, $169 \mathrm{~F} .3 \mathrm{~d} 973$ (5th Cir. 1999).

149. Walker $V, 169$ F.3d at 976.

150. "The Govemment unquestionably has a compelling interest in remedying past and present discrimination by a state actor." United States v. Paradise, 480 U.S. 149, 167 (1987).

151. United States v. Sec'y of Hous. \& Urban Dev., 239 F.3d 211, 219-21 (2d Cir. 2001).

152. Adarand Constructors, Inc. v. Pena, 515 U.S. 200, 237 (1995) (quoting Fullilove v. Klutznick, 448 U.S. 448,519 (1980)). Grutter also repeated this quotation from Fullilove and proved the sincerity of the admonition when it held that the university admissions plan in question survived strict scrutiny. Grutter v. Bollinger, 123 S. Ct. 2325, 2338, 2347 (2003). 
Grutter v. Bollinger, writing: "Narrow tailoring does not require exhaustion of every conceivable race-neutral alternative ...."153 That admonition echoed the Court's deference to lower court orders evidenced in Paradise, where the Court stated that it must "acknowledge the respect owed a district judge's judgment that specified relief is essential to cure a violation of the Fourteenth Amendment" in determining whether a raceconscious remedial order was narrowly tailored. ${ }^{154}$

In its finding that the remedial order was not narrowly tailored, the Walker $V$ court proposed two sets of race-neutral alternatives, both of which involved substantial changes to the policies and expenditures of the DHA. These included, on the one hand, site selection by current density of public housing and neighborhood income level, and, on the other, a programmatic shift towards mobile housing vouchers, with increases in voucher subsidy levels to improve their portability. ${ }^{155}$ The court stated, for instance, that the Section 8 program could improve its success at achieving integration of black families into white areas by "increased funding for both more vouchers and the mobility program, more mobility counselors, and higher fair market exception rents." 156 These changes would require significant increases in program funding, as well as a significant shift towards mobility subsidies and away from housing development. ${ }^{157}$

While both of the circuit's recommended avenues of public housing reform are legitimate, even desirable goals, they were unrealistic and insufficient remedies for the factual context of the case. In the historical record before the court, race, not elass, was the organizing factor animating site and tenant selection decisions by the city council and the DHA. ${ }^{158}$ Furthermore, the district court had already ordered site selection by density and neighborhood income, which ultimately failed to achieve the court's remedial goals. ${ }^{159}$ In fact, some race-neutral criteria were already central to the calculus of site selection practiced by the reformed DHA; as such they had proven to be necessary but insufficient means of preventing segregation. The circuit's finding that integration could be achieved through mobile housing vouchers in lieu of site-based housing demonstrated the

153. Grutter, 123 S. Ct. at 2344.

154. 480 U.S. at 183. The Second Circuit cited similar language from Paradise in its decision in the Yonkers litigation. See United States v. Sec'y of Hous. \& Urban Dev., 239 F.3d 211, 220 (2d Cir. 2001).

155. Walker $V, 169$ F.3d 973, 983-84 (5 $5^{\text {th }}$ Cir 1999).

156. Id. at 985 .

157. Program changes such as these have been widely investigated as policy reforms of the Section 8 program, though they depend on substantial funding shifts and increases. See Hendrickson, supra note 28 , for a policy evaluation of improving desegregation outcomes through mobile housing programs.

158. Walker $V, 169$ F.3d at 976.

159. See Walker 10/6/97 Written Opinion, No. 3:85-CV-1210-R, 1997 WL 33177466, *10 (N.D. Tex. Oct. 6, 1997) (memorandum opinion), rev'd in part, vacated in part, $169 \mathrm{~F} .3 \mathrm{~d} 973$ (5th Cir. 1999). 
court's acceptance of a glacial process of market-led integration in the face of a record of explicit, state-organized segregation. ${ }^{160}$ The court's corollary advice involving increased subsidies for voucher holders constituted an unrealistic policy and budgetary prescription that exceeded both the court's institutional competence and the DHA's resources. ${ }^{161}$ The circuit's prescriptions thus hinged on a narrow tailoring requirement that demanded race-neutrality at the expense of other values, such as timeliness, practicability, responsiveness to eourt orders, and accountability to remedial goals.

\section{A Turn Towards Non-State Actors}

The fourth characteristic of the court's equal protection analysis is especially significant in the housing context: the court's preferred raceneutral alternatives to the remedial order depended heavily on non-state actors. Specifically, the court increased the remedial order's reliance on Section 8 portable housing subsidies, designed for use in the private market. The Walker $V$ court found that such vouchers provided a preferable race-neutral option, because they would allow "market forces" to direct the process of obtaining affordable housing. ${ }^{162}$ Private landlords' discretion in accepting or rejecting tenants holding such vouchers will be discussed infra, but it is important to note that, in the Fourteenth Amendment context, such landlords are not state actors and thus unreachable by equal protection law. ${ }^{163}$ Though the Supreme Court has yet to take up the question, the Second Circuit and other courts have held that though the vouchers are government funded, landlords participating in the program enjoy equal discretion in their choice of tenants as that granted to private landlords. ${ }^{164}$

The assessment that Section 8 vouchers offered a race-neutral, more narrowly tailored alternative to the district court's race-conscious remedy in Walker $V$ represented a factual assumption that the market-driven Section 8 program can fully remedy the unconstitutional segregation perpetuated by public bodies. However, research is increasingly documenting the concentration of Section 8 vouchers in "Section Eight ghettoes" of race and class homogeneity. ${ }^{165}$ Whether or not there is a sound empirical basis for the court's confidence in the voucher model, the key

160. See discussion of housing vouchers infra Part IV.

I61. Courts' competence to make policy prescriptions has been debated since the earliest municipal exclusion and housing desegregation cases. See Charles M. HaAR, Suburbs Under SiEgE: RaCE, SPACE, AND AudaCious Judges (1996).

162. Walker $V, 169$ F.3d at 984.

163. See, e.g., Salute v. Stratford Greens Gardens Apartments, 136 F.3d 293 (2d Cir. 1998). For a discussion of the constraints and possibilities for remedying discrimination in the Section 8 program, see Paula Beck, Fighting Section 8 Discrimination: The Fair Housing Act's New Frontier, 31 HaRv. C.R.-C.L. L. REv. 155 (1996).

164. See Beck, supra note 163.

165. For a synthesis of this literature, see Joseph Seliga, Comment, Gautreaux a Generation Later: Remedying the Second Ghetto or Creating the Third?, 94 Nw. U. L. REv. 1049 (2000). See also infra Part III.B. 
for the court's confidence in the voucher model, the key effect of the decision remains: implementation of the full program of remedial desegregation in Dallas is transferred to the discretion of non-state actors who are unaccountable to the constitutional prohibition on furthering segregation. As such, the government agencies sanctioned for their conduct have little control over whether the program does or does not accomplish desegregation results. This shift of remedial burdens to actors unbound by the court order reduces accountability, therefore risking compromised timeliness and efficacy.

Were it to trickle into Supreme Court equal protection doctrine, Walker $V$ would essentially reopen a question answered by the Court in Gautreaux: how can a housing authority remedy a pattern of discrimination and segregation in such a way as to avoid further concentrations of public housing in high-poverty, minority areas? The Court in Gautreaux offered integration and the liberation of minority housing choice as its answer. The Walker $V$ court, by contrast, ordered that remedies for segregation could not name, and thus not systematically pursue, racial integration.

III

\section{What Remedy? Assessing the INTEgRation MANDATE}

Walker $V$, like Yonkers and other public housing desegregation cases across the country, ${ }^{166}$ illustrates a form of neighborhood conflict between "insiders" and "outsiders" which has been widely contested in the courts and scholarship: the right of residents of a community to exclude public and affordable housing. ${ }^{167}$ Widespread recognition of segregation's harms has generated nearly four decades of litigation to remedy discrimination in the location of public housing. ${ }^{168}$ Such litigation has addressed two main axes of discrimination: the siting of public housing to match the majority race of a neighborhood and the allocation of tenancies based on race within

166. The extensive range of segregation cases brought before courts in recent decades demonstrate the history and on-going effects of public housing's role in the racial division of American cities. The histories of cases in Dallas, Chicago, and Yonkers are discussed in this Comment. For examples of other cities, see United States v. City of Parma, 494 F. Supp. 1049, 1055-59 (N.D. Ohio 1980) (describing the local housing authority's role in perpetuating segregation in Cleveland and its suburban counties), aff'd in part, rev'd in part, 661 F.2d 562 (6th Cir. 1981); Blackshear Residents Org. v. Hous. Auth., 347 F. Supp. 1138, 1141-43 (W.D. Tex. 1971) (documenting the history of segregated public housing in Austin); Hicks v. Weaver, 302 F. Supp. 619, 621-24 (E.D. La. 1969) (describing the role of the housing authority in Bogalusa, Lousiana, in organizing racial segregation). See also Roisman, supra note 35 , at 194 (listing all twenty-eight desegregation lawsuits brought against HUD).

167. For cases involving conflicts over affordable housing generally, see, for example, village of Arlington Heights v. Metro. Hous. Dev. Corp., 429 U.S. 252 (1977); S. Burlington City NAACP v. Township of Mount Laurel, 456 A.2d 390 (N.J. 1983); S. Burlington County NAACP v. Township of Mount Laurel, 336 A.2d 713 (N.J. 1975). For commentary on the contentious history of such cases, particularly the Mount Laurel litigation, see HAAR, supra note 161. For a history of neighborhood racial discrimination and exclusion, see MEYER, supra note 134.

168. See supra note 166 
existing projects. Underlying these claims has been a host of related discrimination issues, such as unequal facilities and maintenance budgets for white and nonwhite developments.

On first glance, a "cease-and-desist" remedy to such discrimination might seem straightforward: prohibit and penalize the consideration of race in the allocation and siting of public housing. But what would enforcement mean? Could state actors purge racial information from their files, but continue to site disproportionate numbers of developments in minority neighborhoods? Across the country, racially concentrated, lowincome communities have already formed, branding cities with an unmistakable racial geography. ${ }^{169}$ Even if the technical purification of tenant assignment practices and equal distribution of site selection were to occur (though there is evidence to the contrary ${ }^{170}$ ), it would provide a feeble corrective for the inertia of thousands of apartments, hundreds of developments, and numerous cities ordered according to race. To seriously disengage the federal government from the business of perpetuating residential segregation, victims of discrimination had to seek integration. Whether cast as remedial or forward-looking, diversity within developments and within neighborhoods has seemed the only means of disengaging state funding for housing from the perpetuation of segregation. ${ }^{171}$

Ongoing litigation efforts to achieve this vision of diversity in housing have used the Fourteenth Amendment, as discussed, as well as the Fair Housing Act (FHA) of $1968^{172}$ and state anti-discrimination laws. ${ }^{173}$ The Department of Justice (DOJ) Civil Rights Division, as well as civil rights, legal aid, and housing advocacy organizations regularly file suit under the FHA against city councils and local public housing agencies that refuse to participate in voucher programs or attempt to block construction of public housing in their districts for reasons apparently pertaining to race. ${ }^{174}$

169. See MASSEy \& DENTON, supra note 27.

170. See Susan J. Popkin et al., Obstacles to Desegregating Public Housing: Lessons Learned from Implementing Eight Consent Decrees, 22 J. Pol.'y ANalysis \& MgmT. 179, 187-88 (2003) (documenting the level of resistance to integrative, scattered site public housing programs in Dallas, as well as Minneapolis, New Haven, and Allegheny County, and summarizing the range of legal remedies employed in the consent decrees of eight major desegregation cases).

171. For a justification of race-conscious remedies in light of the past history of desegregation litigation, see Florence Wagman Roisman, Opening The Suburbs To Racial Integration: Lessons for the 21st Century, 23 W. New ENG. L. REv. 65, 72 (2001).

172. 42 U.S.C. $\$ \S 3601-3619$ (2000).

173. See, e.g., CAL. Civ. CoDE $\S \S 51-51.10$ (West 1982).

174. For a catalogue of the DOJ's civil rights lawsuits in housing (many of which involve the public housing violations discussed in this paper), see http://www.usdoj.gov/crt/housing/. For information on similar cases filed by legal non-profits, see, for example, the National Housing Law Project at http://www.nhlp.org, and the American Civil Liberties Union (ACLU) at http:/www.aclu.org/RacialEquality/RacialEqualitylist.cfm?c=197. The ACLU has filed such a case against the City of Baltimore and its public housing authority; the lawsuit has been called one of the most significant housing lawsuits in two decades. See Eric Siegel, Trial Set On Segregation Claims 
Critics of desegregation litigation wrongly call such cases obsolete; ${ }^{175}$ on the contrary, they remain of vital importance in contemporary civil rights law. ${ }^{176}$ Remedies in such cases, some of which will be discussed in this Part, have involved tailored relief with both race-conscious and raceneutral provisions. A Walker $V$ doctrinal regime threatens a significant chilling effect on such remedies, an outcome that would substantively preserve existing urban racial divisions.

Intersecting these doctrinal changes in available remedies, housing policy has taken a sharp turn towards the private market, a realm in which there is no accountability to remedying segregation and, perhaps, limited promise of improving racial integration. Beyond its consequences for the landscape of equal protection doctrine, then, colorblind segregation jurisprudence threatens two additional effects: first, restricted remedies for segregation and discrimination under the FHA, and, second, over-reliance on market-based mobility programs as a catch-all means of promoting housing intcgration to redress systemic discrimination.

\section{A. Foreclosing Effective Remedies Under the FHA}

With the passage of the FHA, also known as Title VIII of the 1968 Civil Rights Act, Congress mandated that, "[i]t is the policy of the United States to provide, within constitutional limitations, for fair housing throughout the United States." 177 The FHA is the most significant federal statutory protection against discrimination in the sale and provision of housing for tenants, homeowners, and rental applicants in both private and public housing. ${ }^{178}$ Under the statute, the DOJ may bring pattern-andpractice housing discrimination cases, for instance challenging discriminatory public housing assignment and location policies. ${ }^{179}$ These cases against municipal governments and public housing agencies have generally alleged

Against City Housing Authority; Tenants Say Agency, HUD Limited Units To Poor Areas, BAlTIMORE Sun, Nov. 29, 2003, at $1 A$.

175. See, e.g., Schuck, supra note 28 , at 365 (ealling mandatory public housing desegregation a "dinosaur").

176. Florence Wagman Roisman has identified twelve cities where segregation has reached extreme levels in recent years, but where no desegregation litigation has taken place, ineluding: Albany, Gcorgia; Baton Rougc, Lousiana; Flint, Michigan; Trenton, New Jersey; and Washington, D.C. In addition, she identified nine cities with high rates of segregation and large public housing authorities where no remedial desegregation efforts have yet taken place. See Roisman, supra note 35 , at 173-74.

177. 42 U.S.C. $\$ 3601$.

178. See 42 U.S.C. $\$ 3604$. As amended in 1988, the FHA prohibits discrimination in housing on account of race or color, national origin, rcligion, sex, familial status, and disability. Discriminatory conduct may include: making housing unavailable, denying a dwelling, setting different terms or conditions, providing different services or facilities, refusing to sell or rent, or denying access to a facility or service.

179. See 42 U.S.C. $\$ 3614($ a). For a discussion of the struggle to achieve integration using the nondiscrimination principles of the FHA, see Richard H. Sander, Individual Rights and Demographic Realities: The Problem of Fair Housing, 82 Nw. U. L. Rev. 874, 902-13 (1988). 
two categories of racial discrimination, often folded into the same legal action: (1) exclusion of public housing developments based on the anticipated race of the occupants (generally perpetrated by city councils), and (2) failure to site public housing in white neighborhoods where the probable occupants were nonwhite (generally perpetrated by housing authorities). ${ }^{180}$

As a means of understanding the long-term consequences of colorblind desegregation doctrine, this section will explore two case studies of desegregation lawsuits against city councils and public housing authorities. The first case, brought against the housing authority of Jacksonville, Florida, involved a race-conscious plan similar to the type at issue in Walker $V .^{181}$ The case provides an important point of inquiry into the chilling effect that colorblind segregation doctrine would have on remedies to unconstitutional segregation. The second case, brought by the DOJ against the town of Milford, Connecticut, involved a settlement requiring the housing authority to construct new public housing units in non-minority areas. ${ }^{182}$ The case provides an important note of caution on the potential outer reaches of colorblind doctrine in the desegregation context.

In United States v. Jacksonville Housing Authority (Jacksonville), the DOJ alleged intentional racial discrimination in the siting of public housing in Duval County, Florida, manifested in a long-standing pattern and practice of refusing to site public housing in any neighborhoods that were not predominantly black. ${ }^{183}$ Specifically, the complaint alleged housing authority abandonment of an explicitly race-conscious plan to disperse replacement public housing units in white neighborhoods in the face of white resistance. ${ }^{184}$ As part of the case settlement, the Jacksonville Housing Authority was required to build 225 new public housing units in white

180. Cases brought on behalf of plaintiffs from many racial and ethnic groups allege a wide spectrum of discrimination and segregation in public and affordable housing. See United States v. Village of Addison (N.D. Ill. filed Oct. 6, 1994) (alleging that public housing was chosen for demolition based on the race of its occupants); United States v. City of Agawam (D. Mass. filed Sept. 17, 2002) (alleging that a housing plan was rejected based on the probable race of the occupants); United States v. Blakely Hous. Auth. (M.D. Ga. filed June 10, 2002) (alleging the maintenance of segregation among public housing developments and differential terms and conditions of occupancy based on residents' race); United States v. City of Fairview Heights (S.D. 11l.) (alleging that an affordable housing permit was denied based on the expected race of the occupants); United States $v$. Village of Hatch (D.N.M. filed May 9, 1994) (alleging that land-use ordinances were employed so as to exclude affordable housing for low-income Latinos from the city). See http://www.usdoj.gov/crt/ housing/caselist.htm.

181. United States v. Jacksonville Hous. Auth., No. 1165-J-25A (M.D. Fla. filed Oct. 17, 2000), available at http://www.usdoj.gov/crt/housing/caselist.htm\#race.

182. United States v. Hous. Auth. of Milford, No. 396 CV 01118 (D. Conn. filed Apr., 1997), available at http://www.usdoj.gov/crt/housing/caselist.htm\#race.

183. United States v. Jacksonville Hous. Auth., No. 1165-J-25A, ๆ9 6-8, 17 (M.D. Fla. filed Oct. 17, 2000), available at http://www.usdoj.gov/crt/housing/documents/jaxcomp.htm.

184. Id. \ 15. 
areas of Duval County where there was little or no public housing. ${ }^{185}$ It also agreed to create a counseling program to facilitate integration of nonwhite households into white municipalities. Jacksonville demonstrates the type of race-conscious housing integration plan that might be struck down under the colorblind terms of Walker $V$, triggering the reverse discrimination reasoning under the Equal Protection Clause outlined in Part II. As in Dallas, the long-standing practice of failing to site public housing in white neighborhoods would inevitably continue.

In United States $v$. Housing Authority of Milford (Milford), the DOJ alleged that the Milford Housing Authority (MHA) had cancelled a subsidized housing program because of its probable occupation by Latino and African-American families. ${ }^{186}$ According to the complaint, Milford is less than $5 \%$ Latino or African-American. ${ }^{187}$ The program in question involved MHA acquisition of single-family homes (called a "scattered-site" family housing program) and adherence to strict eligibility requirements for any potential residents, including employment, a police check, and home visits. ${ }^{188}$ A majority of households on the MHA waiting list were African-American or Latino, and a majority lived in Milford's neighboring cities of Bridgeport and New Haven. ${ }^{189}$ Following an opposition campaign to the program, the town's Board of Aldermen unanimously passed a resolution demanding "permanent" cancellation of Milford's participation in the federal scattered-site housing program. ${ }^{190}$ The following day, the MHA cancelled the program, noting the mayor and city council's demand in its resolution. ${ }^{191}$

The DOJ sued the MHA and the city for violations of the FHA. ${ }^{192}$ The DOJ's complaint alleged that the public opposition to the program was explicitly rooted in the belief that the new housing would be occupied by African-American and Hispanic families, and that the MHA and the city had no reason to cancel the program other than to appease racially motivated neighborhood opposition. ${ }^{193}$ The DOJ reached a settlement with the MHA, requiring that it follow through on the scattered-site plan, select family applicants in a nondiseriminatory manner, publicize the new program in neighboring communities regardless of their racial composition, and train employees about their rights and responsibilities under fair hous-

\footnotetext{
185. Id., Consent Order, available at http://www.usdoj.gov/crt/housing/documents/jaxsettle.htm.

186. Milford, No. 396 CV 01118 (D. Conn. filed Apr., 1997), available at http://www.usdoj.gov/ crthousing/documents/milfordcomp.htm.

187. Id. If 5 .

188. Id. ๆ 7.

189. Id. ๆ 9 .

190. Id. ๆโ $11,12$.

191. Id. \ 13 .

192. Id. II 1 .

193. Id.
} 
ing laws. ${ }^{194}$ The MHA was thus enjoined from unlawfully discriminating against incoming residents based on race, even if such discrimination represented simple capitulation to private discrimination on the part of white residents. ${ }^{195}$ The settlement obligated the MHA to pursue a scattered-site housing plan with integrationist objectives. ${ }^{196}$

On its own terms, the Milford remedy was a race-neutral plan that might survive the reasoning in Walker $V$. However, the case indicates the potential risks of doctrinal expansion in the area of colorblindness in housing desegregation. Homeowners in communities like Milford might bring suit under Walker $V$ and the Supreme Court case Shaw v. Reno ${ }^{197}$ to claim that their community was implicitly selected for scattered-site housing based on their race. Walker $V$ established the proposition that explicit designation of neighborhoods based on race-in any remedial context--would violate the Equal Protection Clause. Shaw, were it to be extended into this area, would provide the additional proposition that measures which are unexplainable on any grounds other than race will also be subject to strict scrutiny. ${ }^{198}$ Though a case like Milford might lack line-drawing to track demographics of the sort prohibited in Shaw, the existence of extreme segregation in a region might functionally create the same effect. If cities and their suburbs mark extreme divisions among racial groups (as was the case in the metropolitan area encompassing Bridgeport, New Haven, and Milford ${ }^{199}$ ), could housing authority efforts to include suburban towns in their jurisdiction (for the purposes of both vouchers and scattered-site housing) be invalidated as an implicit racial classification under Shaw? While such an analysis requires several layers of extension from the reasoning of both Shaw and Walker $V$, it highlights the risks of the colorblindness path in the desegregation context. Even the race-neutral regimes permitted under the reasoning in Walker $V$ could be curtailed, permitting an extreme (and highly efficient) form of status quo preservation in residential segregation.

While such doctrinal extensions of Walker $V$ are not necessarily imminent, they provide an important note of caution about the chilling effects

194. Id. No settlement has yet been reached with the town of Milford itself, which was accused of unlawfully pressuring the MHA to cancel the program. Id.

195. Id.

196. Id.

197. 509 U.S. 630 (1993).

198. Id. at 643 (holding that principles of equal protection apply "not only to legislation that contains explicit racial distinctions, but also to those 'rare' statutes that, although race neutral, are, on their face, 'unexplainable on grounds other than race."'). The facts in Shaw concerned verifiable drawing of district boundaries on the basis of race, and the holding in the case might in fact be confined to circumstances that are demonstrable in that way. See id. at 636, 644 (describing the oddly shaped boundaries of the district at issue and finding that the boundaries are thus justifiable only in terms of race). The decision also contains extensive language that contextualizes the holding within voting rights jurisprudence in particular and suggests that it may be limited to that context. See id. at 639-42.

199. See supra text accompanying note 187 . 
the case might have on litigation under the Fair Housing Act and the Equal Protection Clause to cure the unconstitutional violation of segregation. Such doctrinal restraints on desegregation, in combination with the policy focus on market-led responses discussed in the next section, would significantly facilitate the preservation of segregation.

\section{B. Reconcentrating the Ghetto: Forcing Vouchers as a Catch-All Solution}

Foreclosure of race-conscious integration remedies in the name of equal protection intersects with a major trend in public housing policy, namely the move to market-based solutions for the problems of concentrated poverty. ${ }^{200}$ Over the last ten years, HUD and local housing authorities have demolished thousands of units of public housing stock across the country under public housing revitalization initiatives such as the "HOPE VI" program. ${ }^{201}$ The widespread removal of publicly managed affordable housing, despite increasing demand in most American cities, has created a tremendous need for replacement housing. ${ }^{202}$ Where HUD has sought to provide substitute housing, it is largely through two types of programs: housing voucher programs (commonly referred to as the Section 8 program $^{203}$ ) and private project-based programs. ${ }^{204}$ Theoretically, both types are promising in terms of racial integration: housing voucher and mobility programs are designed to disperse low-income households across the landscape of metropolitan municipalities, and newly constructed public

200. Fred Fuchs, Introduction to HUD Conventional Public Housing, Section 8 Existing Housing, Voucher, and Subsidized Housing Programs: Part II, 25 Clearinghouse Rev. 990 (1991).

201. HOPE VI is a program of demolition and replacement of distrcssed public housing with an emphasis on building mixed-incomc communities. For a description of the HOPE VI approach to public housing revitalization and replacement, see Ngai Pindell, Is There Hope for HOPE VI?: Community Economic Development and Localism, 35 ConN. L. REv. 385 (2003). See also Harry J. Wexler, HOPE VI: Market Means/Public Ends-The Goals, Strategies, and Midterm Lessons of HUD's Urban Revitalization Demonstration Program, 10 J. AFFoRdable Housing \& Community DEv. L. 195 (2001).

202. Susan J. Popkin, The Hope VI program-What About the Residents?, 1 (2002), http://www.urban.org/UploadedPDF/310593_HopeVI.pdf. In Chicago, for instance, demolitions pursuant to HOPE VI threaten to displace over 1,000 residents, many of whom are expected to become homeless. See Susan J. Popkin et al., Residents at Risk: A Profile of Ida B. Wells and Madden Park (2003), available at http://www.urban.org/UploadedPDF/310824_residents_at_risk.pdf. For a general update on affordable housing need in the United States and its regions, see U.S. Housing Market Conditions (Winter 2003), http://www.huduser.org/periodicals/ushmc/winter03/USHMC03Q4.pdf.

203. See explanation supra note 90 . The Section 8 program is currently in a period of major transition. In February 2005, the Bush administration announced that funds for mobile housing vouchers will be made as block grants to individual housing authorities through a new program entitled the Flexible Voucher Program. See News Release, U.S. Dep't of Hous. \& Urban Dev., Reform to Section 8 Aims to Help Families Achieve Self-Sufficiency (Feb. 12, 2004), http://www.hud.gov/news/ release.cfm?content=pr04-013.cfm.

204. Adams, supra note 29 , at 416 n.2. 
housing is intended to be dispersed into districts with low concentrations of existing public housing. ${ }^{205}$

The Fifth Circuit in Walker $V$ embraced this shift towards marketbased solutions in its reliance on race-neutral policy alternatives for achieving housing integration, particularly the market-based approach of Section 8 and mobility programs. ${ }^{206}$ This focus on vouchers, however, is falsely optimistic about their potential to achieve integration. ${ }^{207}$ While the Section 8 voucher program has been widely heralded as a better model of housing policy, it is not a panacea. ${ }^{208}$ The program now provides the most significant source of federal housing assistance to low- and very low-income people, and its portable subsidies have long been envisioned as a means for low-income urban households to move into higher-opportunity suburbs. ${ }^{209}$ In recent years, however, the program has demonstrated severe limitations in terms of housing quality, dispersal of low-income housing, and tenant housing choice. ${ }^{210}$ Extensive studies on the efficacy of the Section 8 program have shown three common problems which will be discussed below: discrimination by landlords in accepting Section 8 vouchers, the barrier that exclusionary zoning poses to any affordable housing, and (as a manifestation of the first two) the concentration of vouchers in "Section 8 neighborhoods" where poverty rates are high.

Dispersal of low-income housing through housing choice vouchers has been undermined by the reality that many landlords refuse to accept vouchers. ${ }^{211}$ Discrimination against Section 8 voucher holders is widespread, with landlords offering grounds for refusal that range from avoidance of the administrative bureaucracy to negative stereotypes about the living habits of Section 8 tenants. $^{212}$ Only one federal statute offers protections for voucher holders against discrimination, ${ }^{213}$ but scholars have

205. Excepting a small subsection of newly constructed housing, both types of programs arc public-private hybrids in which government subsidies flow into the private market, which in turn provides and manages the housing. As such, the promise of voucher and mobility models to achieve greater racial integration depends on the participation-and nondiscrimination-of private actors, including landlords, lenders, and real estate developers. See infra discussion accompanying notes 211 18.

206. Walker V, 169 F.3d 973, 984 (5th Cir. 1999), cert. denied, 528 U.S. 1131 (2000).

207. See, e.g., Seliga, supra note 165 . For commentary in the popular press, see, for example, John W. Fountain, Suit Says Chicago Housing Renewal Plan Perpetuates Segregation, N.Y. TimEs, Jan. 24, 2003, at A18.

208. See Hendrickson, supra note 28 , at 36 . For a summary of the mechanics of the Section 8 program, see Philip D. Tegeler et al., Transforming Section 8: Using Federal Housing Subsidies to Promote Individual Housing Choice and Desegregation, 30 HARv. C.R.-C.L. L. REV. 451 (1995).

209. For a discussion of the Section 8 program origins and mechanics, see, for example, Rochelle L. Stanfield, Vouching for the Poor, 27 NAT'L J. 1094 (1995).

210. Beck, supra note 163 , at 167.

211. Id.

212. Id. at 163-67.

213. See Housing and Community Development Act of 1987, Pub. L. No. 100-242, § 147, 101 Stat. 1815 (1988) (codified as amended at 42 U.S.C. $\S 1437 \mathrm{f}(\mathrm{t})(2000)$ ). 
argued that the law is structured to prohibit discrimination by landlords who have rented to Section 8 tenants in the past, thereby creating a disincentive for new landlords to enter the voucher market. ${ }^{214}$ Some state statutory protections exist ${ }^{215}$; however, they remain relatively untested as a deterrent for systemic exclusion of Section 8 vouchers from certain neighborhoods. ${ }^{216}$ Indeed, one Second Circuit case held that private landlords are under no obligation to accept Section 8 vouchers under the current FHA. $^{217}$ Scholars have advanced various proposals to limit private discrimination against Section 8 voucher holders, for instance through an amendment to the FHA law barring landlords from refusing Section 8 applicants based on their status as Section 8 participants, but no such legislative action has yet been taken. ${ }^{218}$

In addition to racial discrimination, exclusionary zoning ordinances that erect barriers to affordable housing also undermine the efficacy of the Section 8 program at achieving desegregation. Exclusionary zoning Iaws are race-neutral local ordinances that set standards and minimum requirements (such as lot size, permissible housing types, and amenities) for housing and development. ${ }^{219}$ A study of the effect of such ordinances in the context of metropolitan Dallas observed that the use of exclusionary zoning ordinances in many regional suburbs meant an absence of any rental housing market whatsoever. ${ }^{220}$ As such, the study aptly noted, the efficacy of the Section 8 program at achieving any degree of racial or economic integration of public housing tenants into area suburbs would bc severely curtailed, an outcome that would belie the Fifth Circuit's confidence that Section 8 was an equally effective, race-neutral alternative for achieving remedial deconcentration of public housing. ${ }^{221}$

This private discrimination against Section 8 vouchers in particular and affordable housing in general has led to the reconcentration of the poor into "Section Eight neighborhoods." 222 Administration of the program itself has reinforced the ghettoization of voucher holders, because fractured administration across urban and suburban districts often means that most voucher holders are effectively limited to applying brand new vouchers to

214. See, e.g., Beck, supra note 163, at 167.

215. Mark A. Malaspina, Note, Demanding the Best: How to Restructure the Section 8 Household-Based Rental Assistance Program, 14 Y ALE L. \& PoL'y REv. 287, 315-16 (1996).

216. Beck, supra note 163 , at 168.

217. Salute v. Stratford Greens Gardens Apartments, 136 F.3d 293, 300 (2d Cir. 1998).

218. Beck, supra note 163 , at 171-85. For other proposals to reform Section 8 to prevent discrimination, see Malaspina, supra note 215, at 315, and Roisman, supra note 35, at 173-78.

219. Alice M. Burr, The Problem of Sunnyvale, Texas, and Exclusionary Zoning Practices, $11 \mathrm{~J}$.

AfFordable Housing \& Community Dev. L. 203, 204 (2002).

220. Id. at 205-08.

221. Id. at 218 .

222. Malaspina, supra note 215 , at 315 . 
housing in the same inner city neighborhood in which they have lived. ${ }^{223}$ As such, these programs are creating what has been referred to as the "Third Ghetto," 224 the newest stage in the creation of concentrated, isolated, and racialized islands of poverty facilitated by public housing authorities. Importantly, these re-concentrations of poverty under voucher programs no longer bear the imprimatur of state action-segregation under a market-led housing model is excused as merely the result of multitudes of diffuse, private actions that can be easily rationalized as a capitalist defense of property values. ${ }^{225}$

Yet ironically, Section 8 vouchers are praised for the same reason they have little chance of effecting long-term change as an integration program: they move very few low-income families of color into more resource-rich districts. ${ }^{226}$ Opponents of integration programs tout such slow change as an advantage of the program. ${ }^{227}$ This, then, may well be what remedies for judicially determined constitutional violations are reduced to under the Walker $V$ regime: slow change set at the pace of white tolerance for integration. For a generation of the low-income racialized poor, slow change will mean homes qualitatively similar (and similarly segregated) to a concentrated public housing development, albeit under private management.

In addition to the current limitations on the Section 8 program, it has been slated for major funding changes by the Bush Administration, including the distribution of funding through block grants to housing authorities. $^{228}$ Over the past several years, facing extensive opposition, the administration has lobbied to convert at least three-fourths of current Section 8 funding into state block grants. ${ }^{229}$ Policy analysts warn that such a conversion is accompanied by declining aggregate funding, ${ }^{230}$ and affordable housing advocates warn the plan will limit current protections for

223. See Seliga, supra note 165.

224. Id. This term stems from Arnold Hirsch's well-known coneept of the creation of a "Second Ghetto" in publiely managed public housing. See HiRsch, supra note 28.

225. See Schuck, supra note 28 , at 297-301.

226. See Beek, supra note 163, at 158-59; Malaspina, supra note 215, at 287-88.

227. See, e.g., Schuck, supra notc 28 , at 368.

228. See discussion supra note 203. See also Stephen Koff, Bush Urban Policy Is Cutting Off Cash to Cities, Critics Say, Plain Dealer, Oet. 13, 2003, at A1. Robert Pear, Aid to Poor Faces Tighter Scrutiny, N.Y. Times, Feb. 5, 2003, at Al.

229. The Bush administration's bloek grant reforms of Section 8 have been widely controversial, even among Republicans. See Amy Goldstein, Bush Goes Back to a Balky Congress; Many of His Previous State of the Union Proposals Have Been Stymied, WASH. Post, Jan. 20, 2004, at A11.

230. The Center on Budget and Policy Priorities estimates that the reform could lead to the loss of $30 \%$ of the entire national pool of vouchers by 2009. See Barbara Sard \& Will Fischer, Administration Seeks Deep Cuts in Housing Vouchers and Conversion of Program to a Block Grant 3 (2004), http://www.cbpp.org/2-12-04hous.htm. 
voucher holders. ${ }^{231}$ Though recently defeated, the Administration's efforts in 2004 not to renew spending for the HOPE Vl program, the major policy engine of public housing revitalization and replacement, suggest that major cutbacks may yet occur in that program as well. ${ }^{232}$ In the context of reduced funding for the Section 8 program and potentially for other housing replacement programs, the Fifth Circuit's reliance on vouchers as a panacea of remedial desegregation is all the more unstable.

\section{IV}

\section{The Result: Zones of Exclusion}

The implications of Walker V's particular version of colorblindness extend beyond its doctrinal shadow and significant intersections with housing policy. A regime of colorblind segregation jurisprudence risks the ostensibly race-neutral perpetuation of current patterns of urban inequality along the lines of both race and class. This Part will examine a model for understanding how colorblindness masks the persistence of spatial inequality and will demonstrate why racial integration must be pursued as a remedy for state-organized segregation.

\section{A. Perpetuating Inequality Through Rational Exclusion}

Shortly following the decision in Walker $V$, the attorney for the homeowners told a Dallas newspaper that the decision was "an important step in the direction of a colorblind society."233 His comment begs an important question for equal protection jurisprudence in the housing context: If race-neutrality in Dallas's affordable housing market could be achieved, would such a system remedy the entrenched inequality created by segregation? This section will present a theory of segregation perpetuated by rational exclusion, demonstrating why the advent of race-neutrality in the Dallas public housing market (if something of the sort could be achieved) would preserve the status quo of neighborhood advantage distributed along racial lines. This phenomenon can be called colorblind segregation.

As we have seen, the system of federally funded, de jure and de facto racial segregation of public housing in Dallas (operating through the late I980s) imposed stigmatization, isolation, underfunded and deteriorating physical infrastructure, and inferior public services on West Dallas, the

231. News Release, National Low Income Housing Coalition, Bush proposal will dismantle housing program for lowest income families (Feb, 2, 2004), http://www.nlich.org/press/pr020204.html.

232. Amy Goldstein \& Jonathan Weisman, Bush Seeks to Recast Federal Ties to the Poor, WAsH. Posr, Feb. 9, 2003, at A1.

233. Craig Flournoy, Court Strikes Down Public Housing Ruling; Decision Seen as a Win For Residents in Far N. Dallas, Dallas Morning News, Mar. 17, 1999, at 1 A. 
nation's largest public housing development. ${ }^{234}$ This first stage in the process of transformation towards colorblind segregation can be described as racially explicit segregation, with areas of the city coded for both race and economic status. David Dante Troutt's work on inner-city ghettoes ${ }^{235}$ as "antimarkets" helps to understand the underlying, discriminatory land-use dynamics at work in facilitating segregation and its resultant inequality. ${ }^{236}$ Troutt argued that in middle class communities, land-use policies favored family, safety, pastoral aesthetics, local control, and convenience. ${ }^{237} \mathrm{By}$ contrast, urban policy in poor neighborhoods "depressed the physical environment for families and businesses" by burdening the communities with mixtures of incompatible uses, widespread demolitions for urban renewal projects, and, finally, the siting of antagonistic, massive scale public housing. ${ }^{238}$ As a result, segregation polarized neighborhoods not only in terms of race but in terms of environment, with the inner city ghetto organized as the antithesis of the aspirations and values of middle class life. ${ }^{239}$

Faced with disadvantageous physical conditions and economic exclusion, inner city neighborhoods like West Dallas predictably suffered both socially and economically. ${ }^{240}$ Michelle Adams has explained how the competitive dynamics among racial groups for a scarce resource (such as housing and access to prosperous neighborhoods) operate to preserve inequalities established during a previous era. ${ }^{241}$ Discussing the Walker litigation in particular, Adams explained how segregation, by organizing housing and public services according to race, constructed an anticompetitive social and economic system which preserved the advantages of the dominant racial group in accessing to superior neighborhood services and property values. ${ }^{242}$ Over time, these advantages self-perpetuated by processes such as accumulation of personal wealth, differential access to housing credit in certain neighborhoods, and "white flight" from cities into independent suburbs. ${ }^{243}$ These effects develop cumulatively, dramatically

234. See supra text accompanying notes 49-71. For a description of public housing's involvement in organizing segregation nationally, sce Adams, supra note 29, at 441-42.

235. Troutt describes the "antinorm status" of the ghetto, which is composed of people who are "socially marginalized, racially and ethnically disfavored, working-class, persistently poor...." Troutt, supra note 139 , at 428.

236. Troutt, supra note 139.

237. Id. at $447-51$.

238. Id. at $459-60$.

239. Id. at 475-77. Troutt's model of interdependence also suggests that there will be strong incentives to preserve racial divisions and inequality, as the prosperity of the middle-class "metamarket" relies on the exclusion of poverty and disadvantageous land uses. Id. at 448-50, 459-60. See also Mahoney, supra note 20, at 1357 (arguing that "[ $t]$ he linkage between blackness, poverty, and concentration is part of the same process that linked whiteness, privilege, and exclusion.").

240. See generally Wilson, The Truly Disadvantaged, supra note 26.

241. Adams, supra note 20, at 1109-10, 1149-52.

242. Id. at 1149-52.

243. Id. at $1150-51$. 
slowing equalization of opportunity, and in the process, demand greater personal risk from individuals in all racial groups to achieve any degree of integration.

Even assuming an absence of racial animus, however, the polarized conditions among neighborhoods have generated class-based reasons to exclude public housing residents that nevertheless preserve race-based segregation. As Richard Thompson Ford compelling demonstrated, a raceneutral regime will perpetuate racially identifiable neighborhoods that track economic inequality. ${ }^{244}$ In his model, a "circle of causation" results from an originally segregated urban landscape with inequities in services and opportunities. ${ }^{245}$ Economic inequality and inferior neighborhood conditions, in turn, generate a self-fulfilling, race-neutral justification for separation and exclusion. ${ }^{246}$ Ford then shows how this phenomenon, given momentum by the past, can evolve over time to appear as a simple dynamic of class segregation, unpolluted by race in a society that deems itself post-racism. ${ }^{247}$ Ford's articulation of the way that state action underpins the early formation of the city, as well as its continued forms and policies, provides an essential tool for explaining why colorblindness or nondiscrimination, even if that were to be achieved, is not a cure for the inequality structured by segregation.

Taken together, these stages in colorblind segregation explain why the structure of racialized urban inequality set in place by public housing will self-perpetuate in the absence of intervening integrationist measures, including court orders. Thus, for example, when the DHA was finally forced (as late as the 1980s) to drop the explicit use of race from its policies, tenant assignment systems, and site selection practices, the incentive to preserve segregation already had an economic, race-neutral life of its own. Residents of desirable Dallas neighborhoods rationally believed that the location of West Dallas replacement housing in their communities would decrease property values. That self-perpetuating cycle of segregation and racial discrimination creating severely distressed neighborhoods, thereby generating a race-neutral rationale for excluding their residents, is the key lesson from the history of neighborhoods like West Dallas.

The inaccuracy of this seemingly rational basis for exclusion is demonstrated by research on the subject, ${ }^{248}$ as well as by a side story in Walker itself. A few years before the homeowner plaintiffs of Walker $V$ brought

244. Richard Thompson Ford, The Boundaries of Race: Political Geography in Legal Analysis, 107 HaRv. L. Rev. 1843 (1994).

245. Id. at $1847-49$.

246. Id. at 1849-56.

247. Id. at 1850-52.

248. For a discussion of the irrationality, injustice, and prevalence of the expectation that integration lowers property valucs, see Margalynne Armstrong, Race and Property Values in Entrenched Segregation, 52 U. MıAMI L. REV. 1051 (1998). 
their suit, another group of Dallas homeowners similarly sued the DHA to block the construction of new public housing in their neighborhood. ${ }^{249}$ Their statutory claim was ultimately unsuccessful, and seventy-five units of housing were built on the contested site. ${ }^{250}$ Despite early and wellorganized opposition, the development did not bring the harmful effects that the plaintiff residents expected, ${ }^{251}$ and neighborhood relations have improved dramatically. ${ }^{252}$ The DHA involved community members and neighborhood activists in decision making about the housing design, and incoming tenants were supported with mobility counseling and on-site services. ${ }^{253}$ One Dallas newspaper reported that since the development's construction, "[n]eighborhood groups have largely embraced the development." 254 Another report described that the negative effects expected to stem from the development never materialized. ${ }^{255}$ Such a success story might not be possible in the post-Walker $V$ context, and it reiterates the necessity of avoiding uncritical surrender to assumptions about the rational bases of exclusion.

Underpinning the significance of a state of colorblind segregation is the condition that neighborhoods still matter-in terms of school quality, personal safety, property tax rates, availability of public services, access to jobs and economic activity, and aesthetics. ${ }^{256}$ lncreasing divergence of economic and educational opportunities among neighborhoods within the same metropolitan area has long-term effects as well. For instance, it thwarts class mobility when polarized opportunity perpetuates intergenerational patterns of educational attainment, employment access, and property ownership. ${ }^{257}$ Colorblind segregation, therefore, threatens lasting perpetuation of racialized inequality across multiple axes of opportunity.

\section{B. Serious Remedies to Segregation: The Integration Imperative}

With each passing year that American neighborhoods remain economically and socially polarized, ${ }^{258}$ the question remains: How can statefunded affordable housing disrupt the conditions of inequality perpetuated

249. See 2 POPKIN ET Al., supra note 123, at 3-32.

250. $I d$.

251. Burr, supra note 219 , at 218.

252. 2 Popkin Et Al., supra note 123, at 3-32.

253. Id.

254. Craig Flournoy, High Court Won't Review Dallas Public-Housing Case: Move is Victory For Homeowners Opposing Projects, Dallas Morning News, Jan. 19, 2000, at IA.

255. Burr, supra note 219, at 218.

256. See generally Gerald E. Frug, City Making: Building Communities Without BuildiNG Walls 103-05 (1999). For insights on the interrelationship between property value and education in the context of segregation, see Nancy A. Denton, The Persistence of Segregation: Links Between Residential Segregation and School Segregation, 80 MinN. L. REv. 795 (1996).

257. See Wilson, The Truly Disadvantaged, supra note 26.

258. See MASSEY \& DENTON, supra note 27 (describing the polarized conditions of racialized inner city neighborhoods). 
by their past systems of segregation? By definition, the finding of liability for constitutional violations by a public housing authority obligates that actor to remedy the consequences of its discrimination. The more difficult challenges lurk in assessing those consequences and determining how far, beyond cessation of the unconstitutional conduct, the actor is accountable for dismantling - perhaps even replacing - the edifice it has built. What is a substantive remedy for a system of marginalization and subordination that has mapped racial inequality onto the urban landscape?

As recognized by the Supreme Court in Gautreaux, remedies to segregation cannot simply mean orders to cease and desist. ${ }^{259}$ Meaningful relief in this context necessarily requires taking into account the compound disadvantages wrought by segregation - for individuals, for families, and for racial groups. In order to redress these effects, courts must be permitted to facilitate integration-disrupting the racial boundaries of urban space and the polarization of inequality therein. Colorblind segregation jurisprudence threatens to foreclose equal protection remedies that explicitly promote racial integration. ${ }^{260}$ As the district court in Walker found, raceneutral remedies are necessary but insufficient to achieve the goal of integration. Therefore, the colorblindness doctrine in Walker $V$ undermines serious solutions to the lasting effects of state-led segregation.

A focus on the constitutional right of white homeowners not to be classified based on race prevents courts from ordering defendant housing authorities and city councils to build public housing in the very neighborhoods where they have repeatedly refused to build it: predominantly white areas. Mike Daniel, the attorney for the African-American plaintiffs in the Walker litigation captured this phenomenon in his comments to the press shortly after Walker $V$ was decided: "The court is saying that you can purposefully segregate public housing by keeping it in black areas for decades, you can declare it unconstitutional, but the court cannot order an end to that practice.... It basically allows the violation to continue."261 Such a change in the court's focus draws attention away from the constitutional violations at the root of desegregation litigation and, in so doing, preserves urban racial divisions.

\section{CONCLUSION}

Across the country, public housing neighborhoods are slated for selective or total demolition. Thousands of residents will be displaced, adding to

259. See Hills v. Gautreaux, 425 U.S. 284, 300 (1976).

260. This emphasis on racial desegration as a means of achieving greater equality of opportunity does not contradict claims for "spatial equality," i.e., claims for greater equalization of power and opportunity among white and nonwhite neighborhoods, without necessarily effectuating actual racial integration. See discussion supra note 31.

261. Craig Flournoy \& Todd J. Gillman, Housing Authority Unfazed by Ruling; Chief Stands by Plans to Build in White Areas, Dallas Morning News, Mar. 18, 1999, at 1 A. 
lengthy waiting lists for affordable housing. Some of this replacement housing will be built by federal funds channeled through HUD or, perhaps in coming years, housing block grants to the states. Much of it will be replaced with subsidized vouchers that send tenants into the private housing market. There is little indication that such a shift towards market-led affordable housing will ease the impacts of segregation, including extreme polarization of opportunity marked by both race and class.

These trends in housing policy intersect with an extension of colorblindness jurisprudence into the realm of judicially determined remedies for unconstitutional housing segregation. Walker $V$ is arguably the front line of this new frontier in colorblind jurisprudence: revocation of the ability of courts to employ race-conscious (and thus explicitly integrationist) orders to remedy the effects of past acts of discrimination and segregation. Walker V's outcome violates the case's own procedural and factual history, and the decision erodes the judicial authority to remedy violations of the Fourteenth Amendment's Equal Protection Clause. Under a regime of colorblind remedies, as the lower court in Dallas warned and the case proved, ${ }^{262}$ newly built public housing will either be built in the same lowincome communities of color where it has historically been concentrated, or it will not be built at all.

While there are indications that the Supreme Court may not follow the Fifth Circuit in the direction of Walker $V$, the decision provides an opportunity to consider the results of a colorblind jurisprudence in the residential desegregation context. Finally, the case poses an important question for equal protection doctrine generally: whether the right to be free from the injury of racial classification in a remedial order overwhelms the right to be free from systemic racial discrimination and exclusion. Under the Walker $V$ framework, the inequality built and amplified by state-led segregation can only be challenged by the slow change of race-neutral policies or the good will of private actors. Such an outcome cannot be said to remedy the severe individual suffering and social costs of racial segregation borne in neighborhoods like West Dallas.

262. See Walker 10/6/97 Written Opinion, No. 3:85-CV-1210-R, 1997 WL 33177466, at *10 (N.D. Tex. Oct. 6, 1997) (memorandum opinion), rev'd in part, vacated in part, 169 F.3d 973 (5th Cir. 1999). 